\title{
HAYVANIN KÖTÜ MUAMELELERE KARŞI CEZA HUKUKU VASITASIYLA KORUNMASI HALİNDE MAĞDURUN TESPITII
}

\author{
DETERMINATION OF THE VICTIM WHEN THE ANIMAL IS PROTECTED FROM CRUEL \\ TREATMENT BY MEANS OF CRIMINAL LAW
}

Eylem BAŞ ${ }^{*}$ M (iD

\section{Makale Bilgi}

Gönderilme: 08/11/2020 Kabul: 22/01/2021

\section{Anahtar Kelimeler}

Hayvan,

Ceza Hukuku, Mağdur.

\section{Article Info}

Received: 08/11/2020

Accepted: 22/01/2021

Keywords

Animal,

Criminal Law,

Victim.

\begin{abstract}
Özet
https://dai.org/l0.21492/inuhfd.823249 doi

İnsanlar tarafından hayvanlara karşı kötü muamelelerde bulunulduğuna ilişkin haberlerin son zamanlarda giderek artan bir şekilde gündeme geldiği görülmektedir. Bu durum toplumda tepkilere neden olmakta ve hayvanlara karşı kötü muamelelerde bulunan kimselerin cezalandırılmaları istenmektedir. Zira şu anki mevzuata göre hayvanlara karşı gerçekleştirilen kötü muamelelerin bazıları şartları varsa "malvarlığına karşı suçlar" kapsamında değerlendirilmektedir. Bu nedenle hem 5199 sayılı Hayvanları Koruma Kanunu'nda (HKK) hem de 5237 Türk Ceza Kanunu'nda (TCK) değișikliklerin yapılması öngörülmektedir. Böylece hayvanlara karşı gerçekleştirilen kötü muamelelerin suç olarak düzenlenerek cezalandırılması istenmektedir. HKK'da hayvanlara karşı gerçekleştirilen pek çok kötü muamele ceza hukuku anlamında suç olarak öngörülmese de karşıllı̆ında idari yaptırımın öngörüldüğü kabahat olarak düzenlenmektedir. Ceza hukukunun son araç olma niteliği bakımından doğru bir tercih yapıldığı söylenebilirse de hayvanlara karşı gerçekleştirilen kötü muamelelerin önlenmesi bakımından gereken yeterliliğin sağlanamadığını söylemek mümkündür. Bu çalışmada hayvanlara karşı gerçekleştirilen kötü muamelelerin suç olarak öngörülmesi halinde bu suçun mağduru belirlenmeye çalışılmaktadır. Bu kapsamda suç genel teorisinde mağdur kavramına ilişkin doktrindeki görüşler incelenerek malvarlığına karşı suçlar ayrı tutulmak kaydıyla bu suçun mağdurunun hayvan olmadığı, toplum olduğu sonucuna varılmaktadır.
\end{abstract}

\begin{abstract}
Recently, increasing news on the agenda about human-induced cruel treatments against animals has observed. This situation caused reactions in society. These reactions focused on the need for punishments for people who treat cruelly against animals. At this point, amendments have demanded to be made in both the Law on Animal Protection Numbered 5199 (AP) and the Law on Turkish Penal Numbered 5237 (TP). In this way, punishment for cruel treatments to animals as a crime has aimed. According to the current legislation, some of the cruel treatments against animals have been regulated within the scope of crimes against property. Many of the cruel treatments against animals have been regulated as administrative offences in the AP. This situation could be considered as the right choice in terms of the principle of ultima ratio. On the other hand, it is also possible to say that the required competence could not be achieved in terms of preventing cruel treatment against animals. This study discusses who could be the victim where the act of cruel treatment against animals has regulated as a crime. In this context, when the opinions in the doctrine regarding the concept of the victim in the general crime theory have examined, it has concluded that the victim is not the animal but the society, on the condition that crimes against property have excluded.
\end{abstract}




\section{GİRIŞ}

İnsanlar tarafindan hayvanlara karşı kötü muamelelerde bulunulduğuna ilişkin haberlerin son zamanlarda giderek artan bir şekilde gündeme gelmesi, toplumda tepkilere neden olmakta ve bununla mücadele gereksinimi kanun koyucuyu etkilemektedir. Bu kapsamda hem $\mathrm{HKK}^{\prime} \mathrm{da}^{1}$ hem de TCK' ${ }^{2}{ }^{2}$ değişikliklerin yapılması öngörülmektedir ${ }^{3}$. Böylece hayvanlara karşı gerçekleştirilen kötü muamelelerin suç olarak düzenlenerek cezalandırlması istenmektedir.

Bir fiilin suç olarak öngörülüp öngörülmemesi tarihsel açıdan görecelik arz etmektedir. Zira sahip olunan medeniyet seviyesi, toplumun özellikleri dikkate alındığında zamana ve yere göre değişiklik göstermektedir. Yine örf, adet ve ahlakın gelişmesi de bir etken olarak ortaya çıkmaktadır. Bu kapsamda daha evvel toplumun vicdanıı rahatsız etmeyen bazı fillere karşı ceza yaptırımıyla tepki gösterilmek istenmektedir ki bunlar arasında önemli bir örneği hayvanlara karşı gerçekleştirilen kötü muameleler oluşturmaktadır ${ }^{4}$.

HKK'da ve TCK'da gerçekleştirilmek istenen değişikliklerle "şey” olarak görülen hayvanın artık olması gerektiği üzere "can" olarak görülmeye başlandığını söylemek mümkündür. Ancak bu çalışmada gerçekleştirilmek istenen söz konusu değişiklikler tek tek incelenmemektedir. Suç olarak öngörülmek istenen bu düzenlemelerin mağduru, öncelikle hayvanın hukuki statüsü, ardındansa suç genel teorisinde mağdur kavramına ilişkin doktrindeki görüşler üzerinde durulmak suretiyle incelenmektedir.

\section{HAYVANIN HUKUKI STATÜSÜ}

Hayvanın hukuki statüsünü belirlemek adına "kiş̧” kavramının üzerinde durmakta fayda vardır. "Kişiı"nin Latincedeki karşılı̆̆ olan "persona" kelimesine ${ }^{5}$ bakıldığında eskiden tiyatroda oyuncunun rolünü icra ederken taktığı "maske"yi ifade ettiği görülmektedir'. Rol yapmayı ifade eden söz konusu kelime, daha sonra hayatta oynanan rolü ifade etmek için kullanılmaya başlanmıştır'. Hukuk alanındaysa kişilerin hukuk sahnesinde oynadıkları rol anlatılmaktadır. Bir anlamda hukuk tarafindan verilen karakter maskesidir ${ }^{8}$.

Hukuk, toplumsal ilişkileri düzenleyerek kişiler arasındaki hak ve yükümlülükleri belirler. Sözkonusu hak ve yükümlülüklerin süjesiyse kişilerdir ${ }^{9}$. Bu bakımdan kişi, hukuk tarafindan gerçekleştirilen bir kurgudur, soyuttur ${ }^{10}$, doğal değil, yasal bir meseledir ${ }^{11}$.

Hukukta kişiden bahsedildiğinde akla gelen ilk varlık, gerçek kişi, yani insandır ${ }^{12}$. İnsanla biyolojik ve fiziki bir varlık ifade edilmekteyken, kişiyle insanın hukuksal yönü anlatılmak istenmektedir ${ }^{13}$. Çağdaş hukuk düzenleri bakımından her insan, kişidir ${ }^{14}$. Geçmiş dönemlere bakıldığındaysa örneğin eski Roma hukukunda olduğu üzere ${ }^{15}$ her insanın kişi olmadığı görülmektedir ${ }^{16}$. İnsanın sömürülmesiyle birlikte köleleştirilmesiyle, hak ehliyetine sahip olan ve olmayan insanları ayırabilmek adına kişi kavramına ihtiyaç duyulmuştur ${ }^{17}$. Eski Roma hukukunda insanlar özgür olanlar ve köleler şeklinde ikiye ayrılmakta ${ }^{18}$, özgürler hakların süjesini; kölelerse hakların objesini oluşturmaktayd1 ${ }^{19}$.

\footnotetext{
${ }^{1}$ RG: $1.7 .2004 ; 25509$.

${ }^{2}$ RG: $12.10 .2004 ; 25611$.

${ }^{3}$ Söz konusu kanun teklifleri için bkz. https://www2.tbmm.gov.tr/d27/2/2-3139.pdf; https://www2.tbmm.gov.tr/d27/2/2-3033.pdf; https://www2.tbmm.gov.tr/d27/2/2-2257.pdf; https://www2.tbmm.gov.tr/d27/2/2-1302.pdf; https://www2.tbmm.gov.tr/d27/2/21098.pdf; https://www2.tbmm.gov.tr/d27/2/2-1097.pdf; https://www2.tbmm.gov.tr/d27/2/2-0947.pdf; https://www2.tbmm.gov.tr/d27/2/2-0795.pdf; https://www2.tbmm.gov.tr/d27/2/2-0815.pdf; https://www2.tbmm.gov.tr/d27/2/20825.pdf; https://www2.tbmm.gov.tr/d27/2/2-0831.pdf; https://www2.tbmm.gov.tr/d27/2/2-0446.pdf; https://www2.tbmm.gov.tr/d27/2/2-0015.pdf; https://www2.tbmm.gov.tr/d27/2/2-0360.pdf (Erişim: 8.11.2020)

${ }^{4}$ TOROSLU, Nevzat: Cürümlerin Tasnifi Bakımından Suçun Hukuki Konusu, 1.Bası, Ankara 1970, s.296-297.

${ }^{5}$ TÜRK HUKUK LÜGATI, Türk Hukuk Kurumu, 3.Bası, Ankara 1991, s.307.

${ }^{6}$ GÜRKAN, Ülker: “Kişilik Kavramının Evrimi”, Prof. Dr. Hamide Topçuoğlu’na Armağan, Ankara 1995, s.42.

7 İMRE, Zahit: Medeni Hukuka Giriş, 3.Bası, İstanbul 1980, s.347.

${ }^{8}$ FISCHER LESCANO, Andreas: “Natur als Rechtspersonen”, Zeitschrift für Umweltrecht, 2018(5)4, s.208.

${ }^{9}$ KELSEN, Hans: General Theory of Law and State, (Cev: Anders Wedberg), Cambridge 1949, s.68.

${ }^{10}$ BYDLINSKI, Franz: "Die “Person”" im Recht”, Festchrift Peter Doralt zum 65. Geburtstag, Wien 2004, s.78.

${ }^{11}$ STUCKI, Saskia: "Rechtstheoretische Reflexionen zur Begründung eines tierlichen Rechtssubjekts", Animal Law - Tier und Recht Developments and Perspectives in the 21st Century Entwicklungen und Perspektiven im 21. Jahrhundert, Zürich 2012, s. 152.

${ }^{12}$ WALINE, Marcel:“Törel Kişilik Kuramı”, (Çev: Hamide Uzbark), AÜHFD, 2, 1945, s.306.

${ }^{13}$ TÜRK HUKUK LÜGATI, s.307.

14 DÖRNER, Heiner: Nomos Kommentar, Bürgerliches Gesetzbuch Handkommentar, Baden-Baden 2019, BGB § 1, Rn.1; GUTZWILLER, Max: "Das Recht der Verbandspersonen”, Schweizerisches Privatrecht, Band II, Basel 1967, s.430.

${ }^{15}$ HAUSHEER, Heinz/AEBI MÜLLER, Regina E.: Das Personenrecht des Schweizerischen Zivilgesetzbuches, Bern 2005, s.264-265.

${ }^{16}$ VELIDEDEOĞLU, Hıfzı Veldet: Türk Medeni Hukuku, C.I, Umumi Esaslar, 6.Bası, İstanbul 1959, s. 254.

${ }^{17}$ BYDLINSKI, s.79.

${ }^{18}$ KOSHAKER, Paul/AYITER, Kudret, Modern Özel Hukuka Giriş Olarak Roma Özel Hukukunun Ana Hatları, Ankara 1977, s.76.

${ }^{19}$ ATAAY, Aytekin: Şahıslar Hukuku Birinci Yarım Giriş-Hakiki Şahıslar, 2.Bası, İstanbul 1969, s.18; UMUR, Ziya: Roma Hukuku, Tarihi Giriş-Kaynaklar-Umumi Mefhumlar-Hakların Himayesi, İstanbul 1982, s.361.
} 
Her insan kişiyken, her kişi insan değildir20 . Günümüzde, "kişi” kavramının, bazı özellikleri bulunan kişi ve mal topluluklarını da ifade ettiği görülmektedir. Hukuk düzenince bir varlığın kişi olarak kabul edilmesi mümkün olduğu gibi söz konusu varlığın hakkın konusu yapılması da mümkündür. Bu, kanun koyucunun takdirindedir $^{21}$. Hak sahipliği, bir niteliği ve imtiyazı ifade eder. Kanun koyucu, "kişi”" kavramının içeriğini, kendi etik görüşü ve kanun koyma politikası içinde hareket ederek hangi varlı̆̆a üstünlük tanımak istiyorsa, onu kişi sayarak hak sahibi olma ehliyetiyle donatmaktadır. Bu takdir hakkını kullanırken sosyal gerçeklerle gereksinimleri dikkate almaktadır ${ }^{22}$.

Kişi kavramını açıklayabilmek için medeni hukuka bakmakta yarar vardır" ${ }^{23} 4721$ sayıll "Türk Medeni Kanunu"nun ${ }^{24}$ (TMK) "Birinci Kitabı”nda "Kişiler Hukuku” düzenlenmiş olup, "Birinci Kısmı" "Gerçek Kişiler", "İkinci Kısmı"ysa "Tüzel Kişiler”" başlığını taşımaktadır. Böylece gerçek ve tüzel olmak üzere iki tür kişinin varlığı kabul edilmektedir. Yani hayvan, kişi değildir.

Doktrindeki ağırlıklı görüsse göre, hayvan, hukukun süjesi değil, objesidir ${ }^{25}$. Ancak hukuk düzenince korunan önemli bir objedir. Zira (bazı ülkelerdeki istisnai düzenlemeler dışında) yasal sistem içinde hayvanlara "kişi" olma vasfi verilmemiştir ${ }^{26}$. Hukukun objesiyle, hukukun süjesinin üzerinde egemenlik kurabildiği şey anlatılmak istenmektedir ${ }^{27}$. Ancak "süje", kelime anlamı olarak "konu", dilbilgisi alanında "özne" anlamına geldiğinden ${ }^{28}$, kişiyi ifade etmemektedir. Esasında karışıklıklara yol açmaması nedeniyle "süje" kavramının kullanılmaması ya da kullanılıyorsa da bundan "kişı”nin anlaşılmaması yerindedir.

Hayvanların korunması, gelecek kuşaklara sağlıklı bir şekilde aktarılması gereklidir ${ }^{29}$. Lakin hayvanın "obje" olarak görülmesi, toplumun hayvanlara karşı beslediği duyguyla örtüşmemektedir. Hatta günümüzde sadece hayvanlarla sınırlı kalınmayarak çevreye de bazı hakların tanınması önerilmektedir ${ }^{30}$. Bu kapsamda "kişi" olmayan, ancak "şey" de olmayan, kendine özgü, ama yine de hukukun objesi olmaya devam eden "üçüncü bir kategori”" olarak görülmektedir. Nitekim "İsviçre Medeni Kanunu"na 2003 yilında eklenen m.641a'yla hayvanların eşya olmadığı ancak özel bir düzenleme olmadığı sürece eşyalara ilişkin hükümlere tabi olduğu belirtilmektedir" ${ }^{31}$. Benzer düzenlemeye "Alman Medeni Kanunu"na (Al. MK) 2002 y1lında eklenen m.90a'da da yer verilmektedir. Türk hukuk sisteminde de benzer bir düzenlemeye yer verilmesi gelecek için izlenebilecek yerinde bir tercih olarak kabul edilmelidir ${ }^{32}$. Hayvanın eşya olmadığına ilişkin mevzuattaki söz konusu hükümler, hayvanın ayni hakkın konusunu oluşturmasını değiştirmemektedir. Nitekim Al. MK. m.903/2'de "hayvanin sahibinin, yetkilerini kullantrken hayvanların korunmastna ilişkin özel kurallara uymak zorunda" olduğu belirtilmektedir. Esasında bu, hayvanın kanun koyucu tarafindan özel bir koruma altına alınmak istenmesinden başka bir şey değildir ${ }^{33}$.

Hayvanın eşya olduğunun kabul edilmemesi halinde eşyaya ilişkin hükümler hayvanlara eşya olduklan için değil, ancak eşya gibi sayıldıklan için uygulanmaktadır ${ }^{34}$. Klasik eşya sınıflandırmasının yanında kendine özgü kuralları bulunan yeni bir eşya türünün oluşturulduğu, zira hayvanların "yaratık" olarak dikkate alınması nedeniyle özel eşyalar olduğu da ifade edilmektedir ${ }^{35}$. Türk hukuk sistemindeyse hayvanların eşya sayılmayacağına ilişkin bir düzenleme bulunmadığından ${ }^{36}$, söz konusu tartışmaların pratikte

\footnotetext{
${ }^{20}$ KELSEN, s.96.

21 VON THUR, Andreas: Der Allgemeine Teil des Deutschen Bürgerlichen Rechts, Band 1: Allgemeine Lehren und Personenrecht, 1.Bas1, Leibzig 1910, s.370-371.

${ }^{22}$ DURAL, Mustafa: Türk Medeni Hukukunda Gerçek Kişiler, 3.Bası, İstanbul 1987, s.3-6.

${ }^{23}$ HELVACI, Serap: Gerçek Kişiler, 6.Bası, İstanbul 2016, s.21.

${ }^{24}$ RG: 8.12.2001; 24607

${ }^{25}$ WIELING, Hans Josef: Sachenrecht, Band 1, Sachen, Besitz und Rechte an beweglichen Sachen, 2.Bas, Berlin Heidelberg 2006 , s.56.

${ }^{26}$ WILHELM, Jan: Sachenrecht, 4.Bası, Göttingen 2010, s.30. Latin Amerika'da örneğin Kolombiya'da mahkemeler hayvanların kişi olduğunu ve haklarının bulunduğunu kabul etmektedir. Yine 2016 ylında Arjantin'de "Mendoza Mahkemesi”, "şempanze"nin "kişis" olduğuna hükmetmiştir. Bkz. FISCHER LESCANO, s.206.

${ }^{27}$ ZERRES, Thomas: Bürgerliches Recht: Eine Einführung in das Zivilrecht und die Grundzüge des Zivilprozessrechts, 7.Bası, Berlin Heidelberg 2013, s.33.

28 TÜRKÇE SÖZLÜK, Türk Dil Kurumu, 11.Bası, Ankara 2011, s.2178.

${ }^{29}$ BYDLINSKI, s.81.

${ }^{30}$ Örneğin 2017 yllında Hindistan'da “Uttarkand Yüksek Mahkemesi”, "Ganj Nehri”nin kişi olduğunu kabul ederek haklarının bulunduğuna hükmetmiştir. Bkz. FISCHER LESCANO, s.205.

${ }^{31}$ STUCKI, s.145-146.

${ }^{32}$ OĞUZMAN, M. Kemal/SELiÇi̇ Özer/OKTAY ÖZDEMIR, Saibe: Eşya Hukuku (Eşya), 20.Bası, İstanbul 2017, s.10, dp.32.

${ }^{33}$ WIELING, s.56.

${ }^{34}$ Bir anlamda hayvanın eşya niteliği, yalnızca hayvanları koruma amacıyla bağdaștı̆̆ ölçüde kabul edilmek istenmektedir. Bu kapsamda eşya kavramının esnek, işlevsel ve tarihsel süreç içinde göreceli bir kavram olarak ortaya çıktığı görülmektedir. Bkz. SEROZAN, Rona: Taşınır Eşya Hukuku, 2.Bası, Ankara 2007, s.72.

${ }^{35}$ WILHELM, s.30.

${ }^{36}$ SİRMEN, Lale: Eşya Hukuku, 1.Bası, Ankara 2013, s.9.
} 
bir anlamı kalmamaktadır ${ }^{37}$. Doktrindeki hâkim görüş, hayvanların eşya niteliğinde olduğu yönündedir. Nitekim Yargitay'ın görüşü de bu yöndedir ${ }^{38}$. Örneğin hayvan, ceza hukukunda “eşya müsaderesi”nin konusu edilmektedir ${ }^{39}$.

Bugün Avrupa'daki tüm ülkeler tarafindan her ne kadar birlik arz etmese de hayvanların korunmasına ilişkin yasal düzenlemeler bulunmaktadır ${ }^{40} .15$ Ekim 1978'de Paris “UNESCO”' (BM Eğitim Bilim ve Kültür Örgütü) merkezinde ilan edilen "Hayvan Hakları Evrensel Bildirisi”nde tüm hayvanların "var olma hakkı" öngörülmüştür. HKK m.4/1-a ise "bütün hayvanlar eşit doğar ve bu Kanun hükümleri çerçevesinde yaşama hakkna sahiptir" şeklindedir. HKK'da hayvanların "yaşama hakkı"nın bulunduğunun hükme bağlanması karşısında artık hayvanların "eşya" olarak kabul edilemeyeceği ileri sürülmektedir" ${ }^{41}$. Ayrıca doğada kişi kavramının bulunmadığı ve bu kapsamda kişi kavramının bir kurgunun ürünü olduğu düşünüldüğünde, hayvanların da kişi olarak kabul edilmesinin çelişki olarak değerlendirilemeyeceği savunulmaktadır ${ }^{42}$.

Hayvanların "yaşama hakkı" bakımından ve yaşam hakkıyla sınırlı olacak şekilde bağımsız bir hak ehliyetinin olduğunun kabul edilmesi önerilmektedir. Ayrıca hayvanlara malvarlığı hakları bakımından hak ehliyeti tanınması yerine, gerçek ve tüzel kişilere, örneğin kişinin öldükten sonra arkasında bıraktığ 1 hayvanına ölünceye değin iyi bakılması koşuluyla kazandırmalar yapılması da tavsiye edilmektedir ${ }^{43}$. Cenin, nasıl korunuyor ve bir anlamda yaşama hakkı cenine tanınıyorsa ve medeni hukukta sınırlı bir hak ehliyetine sahipse aynı durumun hayvanlar bakımından da geçerli olması savunulmaktadır. Cenine tanınan bu sınırlı hak ehliyeti nasıl ki annenin yaşama hakkı karşısında zorunluluk durumu nedeniyle korunmuyorsa, hayvanlara da bağımsız bir yaşama hakkının ve sınırlı hak ehliyeti tanınması gerektiği ileri sürülmektedir. Bu kabul, insan hayatıyla karşılaştırıldığında insan hayatının üstün tutulmasını engellemeyecek ancak hayvan üzerinde deney, avcılık gibi fiilleri engelleyecektir ${ }^{44}$. Ancak hayvanlara bazı hakların tanınması esasında onların kişi olarak kabulü amacıyla değil, bazı hayvan "hakları”nın ihlal edilmesinin önüne geçilmesi amacıyladır. Yani amaç, hayvanın korunmasidır.

Günümüzde insanların kişi statüsünü zaman içinde elde ettikleri, örneğin kölelerin, kadınların başlarda kişi olarak kabul edilmedikleri, bunun doğal bir kabulün değil, tarih boyunca gerçekleştirilen bir mücadelenin ürünü olduğu belirtilmektedir. Irka ve cinsiyete dayalı kırılmaları artık türlerin kırılmasının takip edeceği bununsa hayvanlan artık obje olmaktan çıkarak süje haline getireceği söylenmektedir ${ }^{45}$. Lakin bugüne kadar gerçekleşen kırılmaların aynı tür içinde gerçekleştĭgi unutulmamalıdır.

Bir diğer örnekse milletlerarası hukuktan verilmektedir. Milletlerarası hukukta önceleri süjeler devletken, bireyler obje olarak görülmüştür. Zaman içinde insan haklarının uluslararası hukuka girmesiyle birlikte insanın objeliği, özellikle korunmasını gerektiren durumlar karşısında göreceli hale gelmiştir. İnsanın milletlerarası hukuk alanındaki bu konumuyla, hayvanın ulusal hukuk karşısındaki konumunun paralellik arz ettiği belirtilmektedir. Nitekim uluslararası hukukun süjeleri arasında yer alan uluslararası kuruluşlar da insanın korunması düşüncesiyle kabul edilmiştir ${ }^{46}$.

Hayvanların hukukun süjesi haline getirilmesi beraberinde insanların örneğin hayvan eti yiyip yiyemeyeceği, böcekleri öldürüp öldüremeyeceği yahut yine insanlık için gerekli olan bilimsel araştırmaların hayvanlar üzerinde gerçekleştirilip gerçekleştirilemeyeceği gibi pek çok problemi beraberinde getirmektedir ${ }^{47}$. Örneğin “Alman Hayvan Koruma Kanunu”nun 17. paragrafinda tüm hayvanların değil, bir omurgalının ${ }^{48}$ makul bir sebep bulunmaksızın öldürülmesine ya da kötü muamele sonucu ciddi şekilde acı çekmesine ya da hastalanmasına yahut uzun süren veya tekrarlayan şekilde acı çekmesine ya da hastalanmasına neden olunması suç olarak öngörülmektedir. Burada makul sebep kavramı normatiftir ve insanın korunmasına ilişkin menfaatler bakımından nesnel olarak değerlendirilmektedir. Bu kapsamda

\footnotetext{
${ }^{37}$ ORAL, Tuğçe: "Veteriner Hekimin Sözleşme Dışı Sorumluluğu”, TAAD, Yı1:5, (16), 2014, s.321-322.

${ }^{38}$ Yargitay, 7.CD., 26.2.2014, E.2013/13751, K.2014/3034. www.kazanci.com (Erişim: 30.06.2020)

${ }^{39}$ Yargitay 7.CD., 12.10.2015, E.2014/18899, K.2015/19944. www.kazanci.com (Erişim: 30.06.2020)

${ }^{40}$ MICHEL, Margot: “Tierschutzgesetzgebung im Rechtsvergleich: Konzepte und Entwicklungstendenzen”, Animal Law - Tier und

Recht Developments and Perspectives in the 21st Century Entwicklungen und Perspektiven im 21. Jahrhundert, Zürich 2012, s.594.

${ }^{41}$ OĞUZMAN/SELIÇi/OKTAY ÖZDEMIR, s.10.

${ }^{42}$ STUCKI, s.153.

${ }^{43}$ HATEMİ, Hüseyin/OĞUZTÜRK, Burcu Kalkan: Kişiler Hukuku (Gerçek Kişiler-Tüzel Kişiler), 1.Bası, İstanbul 2014, s.9-10.

${ }^{44}$ Yaşam hakkının anayasada gerçekleştirilen bir değişiklikle hayvanlara da tanınması gerektiği yönünde bkz. SUNGURBEY, İsmet, Hayvan Haklan, İstanbul 1992, s.75-76.

${ }^{45}$ STUCKI, s.148-149.

${ }^{46}$ STUCKI, s.151.

${ }^{47}$ RICHTER, Dagmar: "Recht Des Tieres und Menschliche Interessen”, Menschen Rechts Magazin, (2), 2015, s.97.

48 Omurgalı hayvanın evcil olup olmamasının herhangi bir önemi bulunmamaktadır. Bkz. ERBS, George/KOHLHAAS, Max/STÖCKEL, Heinz/Müller-Walter, Markus H.: Strafrechtliche Nebengesetze, München 2018, § 37, Rn.10.
} 
orantllılı ilkesine dikkat edilmektedir ${ }^{49}$. Benzer bir düzenlemenin Türk hukuk sistemi bakımından da öngörülmesinde fayda vardır.

\section{III. "MAĞDUR" VE "MAĞDURIYET" KAVRAMLARI}

HKK m.1'de "bu Kanunun amacı"nın, "hayvanların rahat yaşamlarını ve hayvanlara iyi ve uygun muamele edilmesini temin etmek, hayvanların acı, ıstırap ve eziyet çekmelerine karşı en iyi şekilde korunmalarını, her türlü mağduriyetlerinin önlenmesini sağlamak" olduğu belirtilmektedir. Her ne kadar maddede "mağduriyet" kavramından bahsedilmişse de bu, suç genel teorisinde kendine has bir yeri bulunan "mağdur" kavramından farklıdır.

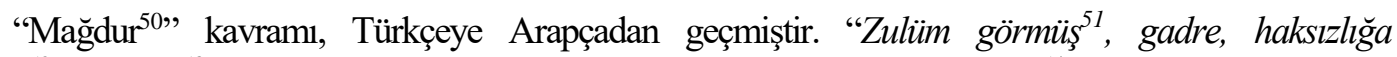
uğramış " ", "klyggin ${ }^{53}$ " anlamına gelmektedir. Mağdur, "gudre"den gelen ve "gadr ${ }^{54}$ " mastarından türetilmiş olup; "gadr", hainlik, zulüm, merhametsizlik, haksızlık, sözleşme nedeniyle vefasızlı̆a uğrama ${ }^{55}$, sözleşmenin bozulması şeklinde tanımlanmaktadır". "Mağdur etmek", haksızlığa uğratarak zor durumda bırakmak; "mağdur olmak", haksızlığa uğrayarak zor durumda bulunmak anlamındadır ${ }^{57}$. Esasında olumsuz bir anlama sahiptir ve kimse mağdur olmak istemez ${ }^{58}$. Mağdurun söz konusu olumsuz anlamı nedeniyle "ilgili kişi” şeklinde ifade edilmesi önerilmektedir ${ }^{59}$.

"Türk Hukuk Lügatı"nda mağdurun gerçekleștirilen bir suç ya da haksız fiil nedeniyle zarar gören kişi olarak tanımlandığı görülmektedir ${ }^{60}$. Yani herhangi bir hukuk kuralının ihlali nedeniyle zarar gören kimse mağdurdur ${ }^{61}$. Bu kapsamda özel hukukta haksız fiil nedeniyle zarar gören kişi mağdur olarak nitelendirilmektedir ${ }^{62}$. Nitekim Yargitay'ın da bu yönde kararları mevcuttur ${ }^{63}$. Ancak ne TMK'da ne de 6098

\footnotetext{
${ }^{49}$ MICHEL, s.616-617.

50 İngilizcede mağduru ifade etmek için "victim” kelimesi kullanılmaktadır. Bu kelime Latince kökenli olup, kutsal ve insanlara yasak olan anlamına gelen "victima" kelimesinden gelmektedir. Bkz. LIBERMAN, Anatoly: An Analytic Dictionary Of English Etymology, Minnesota 2008, s.217, 347. Bu kavrama İncil'de olduğu gibi dinde de yer verildiği ve "kurban” anlamında kullanıldığı görülmektedir. Bkz. FLETCHER, George P.: Basic Consepts of Criminal Law, 1.Bas1, New York 1998, s.32. Zira "kurban”, Tanriya sunulan canlı varlık anlamına gelmektedir. Bkz. SOKULLU AKINCI, Füsun/Dursun, Selman: Viktimoloji (Mağdurbilim), 3.Bası, İstanbul 2016, s.3. Dilbilimciler tarafindan gerçekleştirilen çalışmalarda pek çok kültürde bu kavramın dini fedakârlıkla ilgili olduğu görülmektedir. Bu kapsamda, masum olan olarak kabul edilmektedir. Bkz. BERGELSON, Vera: Victims' Rights and Victims' Wrongs Comparative Liability in Criminal Law, 1.Bası, California 2009, s.1. Nitekim insanlar, gönüllü veya zorunlu olarak başka bir insanı ya da hayvanı, kefaretini ödemek için feda etmekte ve feda edilen şey için "kurban" ifadesi kullanılmaktadır. Mistik veya dini bir kavramı çağrışırması, hukuki anlamı bakımından soruna neden olmaktadır. Zira ister istemez dini anlamını bünyesinde barındırmaktadır. Ayrıca "kurban" ifadesi, çaresizliği ve pasifliği ifade etmektedir. Almancada mağduru ifade etmek için kullanılan "opfer” kelimesi, İngilizcede olduğu gibi "kurban" anlamına da gelmektedir. Savaş döneminde halktan vatan için kendini feda etmesinin istenmesi ve kendisini feda edenlerin savaş mağduru olarak nitelendirilmesi bu kapsamda düşünülmektedir. Yine söz konusu durum pek çok romana, siyasal düşünceye konu edilerek fedakârllk ve mağdurluk kavramları popülerleştirilmektedir. Ancak her ne kadar suç mağduru için bazen "kurban" kavramı kullanılsa da teknik hukuk açısından doğru bir kavram değildir. Bkz. VON MAYENBURG, David: "Geborene Opfer”, Zeitschrift des Max-Planck-Instituts für europäische Rechtsgeschichte, 14, 2009, s.125-126. Nitekim Türk hukuk sisteminde "victim"in tam karşllığı olan "kurban" yerine "mağdur" kavramının tercih edildiği görülmekteyse de (bkz. TÜRKIYE BÜYÜK MILLET MECLISİ İNSAN HAKLARINI İNCELEME KOMISYONU, Mağdur Hakları İnceleme Raporu, 24. Dönem, 4. Yasama Y1lı 2014, s.69) doktrinde "kurban" kavramını kullananlar da bulunmaktadır. Bkz. ONURSAL, Sami: Kamu Davasına Müdahale, 1.Bası, İstanbul 1968, s.41; TANER, Tahir: Ceza Hukuku Umumi Kısım, 3.Bası, İstanbul 1953, s.431; DEMIRBAŞ, Timur: Ceza Hukuku Genel Hükümler, 14.Bası, Ankara 2019, s.214.

51 AYVERDİ, İlhan: Misalli Büyük Türkçe Sözlük, C.2, 4.Bası, İstanbul 2011, s.1918.

52 NISSANYAN, Sevan: Sözlerin Soyağac1, 3.Bası, İstanbul 2007, s.300.

53 TÜRKÇE SÖZLÜK, s.1603. "Kıygı" ise haksızlık, gadir, zulüm anlamına gelmektedir. "Kıygın", mağduru; "kıygınlık" ise mağduriyeti ifade etmektedir. Bkz. AÇIKGÖZOĞLU, Muhammet: Ceza Hukuku Açısından Teori ve Uygulamada Mağdur Kavramı, 1.Bas1, Ankara 2000, s.13.

${ }^{54}$ DEVELLIOĞLU, Ferit: Osmanlıca - Türkçe Ansiklopedik Lugat, 31.Bas1, Ankara 2015, s.314.

${ }^{55}$ Bu kapsamda hakkını alamamış, "hıyanet görmüş", "muhtaç" kimse olarak da tanımlanmaktadır. Bkz. YELBAŞI, Cengiz: Fransızcaİngilizce-Almanca Karșllklarıyla Ansiklopedik Hukuk Sözlüğü, 1.Bası, Ankara 2014, s.383.

${ }^{56}$ AKDEMIR, Süleyman: Ceza Hukukunda Mağdurun Korunması, İstanbul Üniversitesi Sosyal Bilimler Enstitüsü Hukuk Fakültesi Kamu Hukuku Bölümü Ceza ve Ceza Usul Hukuku Anabilim Dalı, Yayınlanmamış Doktora Tezi, İstanbul 1984, s.8.

${ }^{57}$ KANAR, Mehmet: Osmanlı Türkçesi Sözlüğ̈̈, C.2, 1.Bası, İstanbul 2009, s.1972.

${ }^{58}$ Nitekim "Cinsel Şiddetle Mücadele Derneği” tarafindan, cinsel saldırıya uğrayanları ifade etmek için medyada "mağdur" ya da "kurban" yerine "hayatta kalan" kavramının kullanılması önerilmektedir. Zira aksi halde saldırıya uğrayanı zayıflatan ve mağdurlaştıran bir dilin tercih edildiği ifade edilmektedir. http://cinselsiddetlemucadele.org/2016/06/26/kavram-tartismalari-1/ (Erişim: 30.06.2020)

${ }^{59}$ Hatta okullarda öğrencilerin birbirlerine "sen mağdur" diyerek birbirlerini küçümsedikleri yönünde bkz. KNORRE, Hedwig V.: Das Erste Grosse BetrugsOpfer Buch, 2.Bas1, Berlin 2014, s.233.

${ }^{60}$ TÜRK HUKUK KURUMU, s.213.

${ }^{61}$ AKDEMIR, s. 10.

62 TÜRKIYE BÜYÜK MILLET MECLISI İNSAN HAKLARINI INNCELEME KOMISYONU, s.2.

63 Yargitay 17.HD., 25.12.2018, E.2016/7145, K.2018/12793; Yargitay 17.HD., 18.12.2018, E. 2016/3333, K.2018/12331. www.kazanci.com (Erişim: 30.06.2020)
} 
sayll Türk Borçlar Kanunu'nda ${ }^{64}$ mağdur kavramına yer verilmiştir. "Mağduriyet" ise mağdur olma hali için kullanilan isimdir ${ }^{65}$.

Günümüzde mağdura yönelik akademik ve politik ilginin giderek artması ${ }^{66}$ ve toplumu etkileyen bazı olayların sonucunda, mağdur kavramının sınırlarının genişlediği ve çeşitli mağdur sınıflandırmalarının yapıldığı görülmektedir. Bu nedenle mağdur kavramının rafine edilmesi kolay değildir ${ }^{67}$. Suç nedeniyle mağdur olma mağduriyetin ilk akla gelen hallerinden biridir. Ancak bu kavram daha evvel bahsedildiği üzere hukuk dışında da kullanılmaktadır. Herhangi bir konuyla ilgili ortaya çıkan mağduriyete neden olan olayın sonuna "-zede" eki eklenmek suretiyle mağduriyet şekillerinden bahsetmek mümkündür. Örnek olarak depremden etkilenen kişiler için "depremzede" ifadesinin kullanılması verilebilir ${ }^{68}$. Ancak bu kimseler her ne kadar doğal afet nedeniyle acı çekseler de ceza hukuku anlamında mağdur değillerdir. Zira devletin depremi önleme yükümlülüğünden bahsedilemezken, suç işlenmesini önlemek konusunda bir yükümlülüğü bulunmaktadır ${ }^{69}$. Viktimolojideyse mağdurdan yalnızca ceza hukukunda mağdurun mu yoksa doğal afetler, yoksunluklar, hastalıklar ve kazalar neticesinde mağdur olanlarında $\mathrm{m}$ anlaşılması gerektiği konusunda fikir birliği bulunmamaktadır. Yapılan araştırmalar, suç mağduru olmayanların da kendilerini adaletsizliğin ya da keyfiliğin mağduru olarak nitelendirdiklerini göstermektedir. Hatta "Dünya Viktimoloji Topluluğu" gibi küresel ölçekteki topluluklar, kendi ülkelerinde ırkçı, cinsiyetçi, dini ya da siyasi baskıya uğrayanların, her ne kadar açıkça kabul edilmese de mağdur olduğunu kabul etmektedir. Zira bu kimseler, kendilerini diğer ulusların insanlarıyla karşılaştırdıklarında haksızlığa uğradıklarını düşünmektedirler. Ulusal bazda bu kimselerin mağdur olup olmadıklarının dikkate alınmasıysa uluslararası bağlamda insan hakları bakımından yerinde bir tercih olarak kabul görmemektedir ${ }^{70}$.

"Mağdur" kavramının bu denli genişletilmesi, çeşitli mağdur gruplarının yaşadığı travma veya şokun yanında farklı travma türleriyle baş etmedeki benzerliklerine dayanmaktadır ${ }^{71}$. Söz konusu kategorileştirme mağdurlarla ilgili politikalar bakımından özellik arz eder. Bu politikalar oluşturulurken şoka veya travmaya neden olan olayların mağdurlarını kapsayan evrensel ya da ulusal hukukta öngörülen suçların mağdurlarına yönelik özel bir yaklaşım izlenebilir. Ara bir yaklaşımsa insanın neden olduğu tehlike veya zarardır. Yani insanın, insan yapısının veya kuruluşların neden olduğu fiilin mağdurlarından bahsedilmesi mümkündür ${ }^{72}$.

\section{IV.SUÇ GENEL TEORİSİNDE "MAĞDUR" KAVRAMI}

"Mağdur", her ne kadar hukukta ve özel olarak ceza hukukunda olmasa da daha evvel belirtildiği üzere toplumun algısında geniş bir anlama sahiptir ${ }^{73}$. TCK'da ve 5271 sayll Ceza Muhakemesi Kanunu'nda ${ }^{74}$ (CMK) tanımı yapılmamışıı ${ }^{75}$. Ceza ve ceza muhakemesi hukuku bakımından doğurduğu sonuçlar dikkate alındığında, sınırlarının çizilmesi önemli bir ihtiyaç olarak ortaya çıkmaktadır ${ }^{76}$. Örneğin zincirleme suç, haksız tahrik, "hapis cezasının ertelenmesi”, etkin pişmanlık hükümleri, müsadere, dava zamanaşımının başlangııı bakımından mağdurun tespiti gereklidir. Ceza muhakemesi hukuku bakımından ceza davasına katılma ve bu hak dışında kalan muhakemenin evrelerine göre değişebilen diğer mağdur haklarının ${ }^{77}$ kim

\footnotetext{
${ }^{64}$ RG: $4.2 .2011 ; 27836$.

${ }^{65}$ WEBSTER'S THIRD NEW INTERNATIONAL DICTIONARY, Springfied, Massachusets 2002, s.2550.

${ }^{66}$ EDWARDS, Ian: “An Ambiguous Participant, The Crime Victim and Criminal Justice Decision-Making”, The British Journal of Criminology, 44(6), 2006, s.967.

${ }^{67}$ BRIENEN, Marion Eleonora Ingeborg/HOEGEN, Ernestine Henriette: Victims of crime in 22 European criminal justice systems: The implementation of Recommendation (85) 11 of the Council of Europe on the Position of the Victim in the Framework of Criminal Law and Procedure, Nijmegen 2000, s.25.

${ }^{68}$ Mağduriyete neden olan olayın sonuna "zede" ekinin eklenmesi suretiyle sınırsız bir şekilde mağdur tiplerinin oluşturulmasının mümkün olduğu yönünde bkz. DİNLER, Veysel: "Mağduriyet Kavramına Çok Yönlü Yaklaşım”, Suç Mağdurlar, Ankara 2006, s.4950.

${ }^{69}$ BAYLEY, James E.: "The Concept of Victimhood”, To Be A Victim Encounters With Crime And Injustice, New York 1991, s.5556.

${ }^{70}$ BAURMANN, Michael C./SCHÄDLER, Wolfram: Das Opfer nach der Straftat - seine Erwartungen und Perspektiven, Eine Befragung von Betroffenen zu Opferschutz und Opferunterstützung sowie ein Bericht über vergleichbare Untersuchungen, Wiesbaden 1999, s.23-24.

${ }^{71}$ Nitekim batı Avrupa ülkelerinde "Mağdur Destek Hizmetleri”nin giderek doğal afet mağdurlarını da kapsama alacak şekilde hedef gruplarını genişlettiği görülmektedir. Bkz. MAĞDUR HAKLARI DAİRE BAŞKANLIĞI, Yurt Dışı İnceleme ve Çalş̧ma Ziyareti Raporlar, Ankara 2016, s.9.

72 AERTSEN, Ivo: “Karşlaştırmalı Avrupa Ülkeleri Mağdur Hakları Mevzuatı Türkiye'de Mağdur Haklarının ve Mağdurlara Verilen Hizmetlerin Güçlendirilmesi: Etkin Uygulamaya Doğru”, Uluslararası Mağdur Hakları Sempozyumu, 30-31 Ekim Ankara 2014, s.81.

${ }^{73}$ LIU, Jessie K.: "Victimhood", Missouri Law Review, 71(1), 2006, s.128. Nitekim teolojik, psikolojik ve hukuki açıdan farklı anlaşılmaktadır. Bkz. BAURMANN/SCHÄDLER, s.23.

${ }^{74}$ RG: $17.12 .2004 ; 25673$

75 Ancak örneğin Avusturya CMK par.65'te "mağdur" ve "ilgili" kavramlarının tanımına yer verilmiştir. Kanun metni için bkz. https://www.jusline.at/gesetz/stpo/paragraf/65 (Erişim: 30.06.2020)

${ }^{76}$ LIU, s.115.

${ }^{77}$ HELLMANN, Uwe: Strafprozeßrecht, Berlin Heidelberg 1998, s.164.
} 
tarafindan kullanılacağının belirlenmesi, mağdur kavramının tanımlanarak sınırlandırılmasını gerektirir ${ }^{78}$. Yine infaz hukuku bakımından denetimli serbestlik tedbiri uygulanan kimselerin mağdura zarar verip vermeyeceğinin değerlendirilmesi gerektiğinden ${ }^{79}$ mağdurun belirlenmesi gereklidir.

"Mağdur" kavramının sınırlarını oldukça genişleten ve de daraltan anlayışlar söz konusudur. Ancak zaman içinde yerinde olarak bu kavramın kapsamını genişleten anlayışların terk edilerek, suçun hukuki konusunun ve suçun ihlal edici özelliğinin temel alınarak tanımlandığı görülmektedir. Bu yaklaşıma karşın, mevzuatta "mağdur" kavramı belli bir anlayışın eseri olarak kullanılmamaktadır ${ }^{80}$.

TCK ve CMK dışında mevzuattaki düzenlemelere bakıldığındaysa "mağdur"un tanımlandığı hükümlerin bulunduğu görülmektedir. Nitekim "Ceza Muhakemesinde Beden Muayenesi, Genetik İncelemeler ve Fizik Kimliğin Tespiti Hakkında Yönetmelik"te "t1 "tanımlar" başlıklı m.3'te "bu yönetmelikte geçen" mağdur ifadesinden "suçtan veya haksız fiilden zarar gören kişi"nin anlaşılması gerektiği belirtilmiştir. Ancak söz konusu tanım "suçtan zarar gören" kavramıyla arasındaki fark gözetilmeksizin ${ }^{82}$ ve hatta "suçtan zarar gören" kavramından dahi geniş olup kanun koyucunun tanım yapmaktan kaçındığı bir hususun yönetmelikle tanımlanmasının yerinde bir tercih olmadığı yönünde eleştirilse $\mathrm{de}^{83}$ bu tanımın yalnızca ilgili Yönetmelikte geçen mağdur ifadesi için dikkate alınacağının altı çizilmelidir. "Denetimli Serbestlik Hizmetleri Yönetmeliği ${ }^{84 " ~ m .4 / 1-p ' d e y s e ~ m a g ̆ d u r u n ~ " k e n d i s i n e ~ v e y a ~ b i r i n c i ~ d e r e c e d e n ~ a i l e ~}$ üyelerinden birine karşı işlenen suçun fiziksel, duygusal veya maddi sonuçları sebebiyle desteğe ihtiyaç duyan kiş̧i" şeklinde tanımlandığı görülmektedir. Yine söz konusu tanımın da ilgili Yönetmelik kapsamında yer alan mağduru tanımlamak için öngörüldüğü unutulmamalıdır.

Son zamanlarda suçtan kaynaklanan mağduriyetin giderilmesi hususunda sosyal devlet ilkesi gereğince devletin aktif bir rol alarak, meydana gelen zararın kamuya dağıtılması ve devlet bütçesinden ayrılan bir fonla zararın giderilmesi yönünde çalışmalar bulunmaktadır ${ }^{85}$. Bu kapsamda 2020 yılında yürürlüğe giren "Suç Mağdurlarının Desteklenmesine Dair Cumhurbaşkanlığı Kararnamesi ${ }^{86 "}$ m.2-d'de "mağdur", "suç nedeniyle fiziksel, ruhsal veya ekonomik olarak doğrudan zarar gören gerçek kişıl" şeklinde tanımlanmıştır. Söz konusu tanımın ilgili Kararnamenin uygulanması bakımından geçerli olduğuna ve "suçtan zarar gören"i kapsamına aldığına dikkat edilmelidir. Nitekim bu tanım ceza hukukundaki "mağdur" tanımına nazaran geniştir ${ }^{87}$. Ayrıca her ne kadar yalnızca adı geçen Kararnamenin uygulanmasıyla ilgili olsa da mevzuatta ilk kez mağdurun "gerçek kiş̧” olacağına ilişkin bir iradenin açıklandığı görülmektedir.

Ceza hukuku kapsamında mağdura ilişkin tanımlamalar bulunmaktadır. Örneğin bu tanımlamalardan biri kendisine karşı suç işlenen kimsenin mağdur olduğu yönündedir ${ }^{88}$. Mağdurun suçun maddi unsurunun etkilediği kiş̧ ${ }^{89}$ ve bu kapsamda özel ve dar bir anlamının bulunduğu ${ }^{90}$, fail tarafindan gerçekleştirilen suçun yıkıcı etkilerini bizzat yaşayan kişi olduğu, devletin koruma yükümlülügünün ihlali neticesinde zarara uğradığ $1^{91}$, ceza normuyla korunmaya çalı̧ıllanın mağdur olduğu doktrinde ileri sürülmektedir ${ }^{92}$.

İşlenen herhangi bir suça muhatap kılınan herkesin, mağdur olarak kabul edileceği de ileri sürülmüsşür. Bu nedenle mağdur kavramının sınırlarııı belirlemek adına "zarar teorisi” ortaya atılmıştır. Meydana gelen

\footnotetext{
${ }^{78}$ ABD'de, mağdur haklarından yararlananların belirlenebilmesi için mağdur kavramının tanımı her eyalette farklı şekilde yapılmaktadır. Bu nedenle hakların kullanımı bakımından mağdurun nisbiliğinden bahsedilmektedir. Bkz. TRULSON, Chad R.: "Victims' Rights and Services: Eligibility, Exclusion, And Victim Worth”, Reaction Essay, 4(2), 2005, s.399, 402-403.

${ }^{79}$ SOKULLU AKINCI/DURSUN, s.23-24.

${ }^{80}$ KATOĞLU, Tuğrul: “Ceza Hukukunda Suçun Mağduru Kavramının Sınırları", AÜHFD, 61(2), 2012, s.689.

${ }^{81}$ RG: $1.6 .2005 ; 25832$.

${ }^{82}$ KAZAKER, Gözde: Kamu Davasına Katılma, 1.Bası, Ankara 2019, s.60.

${ }^{83}$ PAMUK, Gülfem: Türk ve Fransız Ceza Muhakemesi Hukuku'nda Mağdurun Makam Olarak Yeri, 1.Bası, İstanbul 2012, s.157.

${ }^{84}$ RG: 5.3.2013; 28578

${ }^{85}$ EDWARDS, s.967.

${ }^{86}$ RG: $10.06 .2020 ; 31151$

87 Türk Tabipleri Birliği'nin “Suç Mağdurlarına Yardım Hakkında Kanun Tasarısı' üzerine görüş (20 Kasım 2009)'”ü için bkz. http://www.ttb.org.tr/makale_goster.php?Guid=f7936950-923f-11e7-b66d-1540034f819c (Erișim: 30.06 .2020 ) Esasında bu sorunun temelinde TCK'da ve CMK'da "mağdur"'un ve "suçtan zarar gören"in tanımına yer verilmemesinin yattı̆̆ yönünde bkz. KAFES, Veli: “Ceza Hukukunda Mağdurun Zararının Giderilmesi”, AÜHFD, 60(1), 2011, s.147-148.

88 ÜNVER, Yener: Ceza Hukukuyla Korunması Amaçlanan Hukuksal Değer, 1.Bası, Ankara 2003, s.140; VIDAL Georges/MAGNOL, Joseph: Ceza Hukuku, (Çev: Şinası Z. Devrin), Ankara 1946, s.66.

${ }^{89}$ YÜCEL, Mustafa Tören: Türk Ceza Siyaseti ve Kriminolojisi, 4.Bası, Ankara 2007, s.38; ŞAHİN, Cumhur/GÖKTÜRK, Neslihan: Ceza Muhakemesi Hukuku-I, 10.Bası, Ankara 2019, s.124.

90 TÜRKIYE BÜYÜK MILLET MECLİSI İNSAN HAKLARINI İNCELEME KOMISYONU, s.4.

${ }^{91}$ DEĞíRMENCI, Olgun: "Ceza ve Ceza Muhakemesi Hukukunda Mağdur Hakları”, TBBD, (77), 2008, s.76. Bu zarar fiziksel, psikolojik ya da ekonomik olabilir. Bkz. GRIFFIN, John Brian: "Participation of The Public and Victims in Criminal Justice Adriministration", UNAFEI Resource Material Series No:56, Fuchu, Tokyo, Japan 2000, s.39; ASLI, Mehrdad Rayejian: "Iranian Criminal Justice System in Light of International Standards Relating to Victims", European Journal of Crime, Criminal Law and Criminal Justice, 14(2), 2006, s.187-188.

${ }^{92}$ LIU, s.119.
} 
zararın veya tehlikenin ağıllı̆̆, cezanın belirlenmesinde önemli bir etkendir. Herhangi bir zarara veya tehlikeye neden olmayan bir fiilin suç olarak düzenlenmesinden bahsedilemez. "Göze göz, dişe diş" veya "kısas" denilen sistemde dahi bu durumun esas alındığını söylemek mümkündür. Failin işlediği fiil nedeniyle pek çok tehlike veya zarar ortaya çıkabilir. Ancak bu teoriye göre mağdur kavramının, kast edilmeyen, öngörülemeyen veya öngörülemeyecek şekilde zarar görmüş kişileri içerecek şekilde genişletilmemesi gereklidir. Psikolojik zarar, bu kapsamda örnek olarak verilebilir, zira oldukça belirsizdir ve teorik olarak her şeyi içerebilir. Çoğu zaman zarar görmüş bir kişinin suçlunun niyetinden uzaklığyyla, ortaya çıkan zararın ciddiyeti arasında bir ilişki vardır. Örneğin, gazetede "kasten öldürme" suçuna ilişkin bir haberi okuyan, on dakika endişe duyan ve daha sonra olayı tamamen unutan bir kimse, iki nedenden ötürü mağdur statüsü için uygun değildir. İlki failin ona zarar vermek niyetinin olmaması, ikincisiyse zararnn önemsiz olmasıdır ${ }^{93}$. Ancak bu durumda işlenen suç, üçüncü kişiler bakımından kendilerinin de bu suçun mağduru olabileceği şeklinde bir endişeye sebebiyet vermektedir ${ }^{94}$.

Mağdurun öne çıkması esasında maddi ceza hukukuyla başlamıştır. Zira kanunda öngörülen suçların tanımının çoğunda failin fiilinin mağdur üzerindeki etkisinden bahsedilmektedir ki bu kapsamda "zarar teorisi”nden yararlanıldığı görülmektedir. Örneğin "kasten öldürme" suçunda mağdurun ölmesi gerekliyken, mağdurun ölmemesi halinde bu suça teşebbüsten bahsedilir ${ }^{95}$. Teşebbüs aşamasında kalan suçlarda da mağdur bulunmaktadır ${ }^{96}$.

Mağdur konusu oldukça geniş boyutludur. İnsan hakları, hukuk devleti, sosyal devlet bakımından da mağdura bakmak mümkündür. Bu kapsamda, mağduriyet halinde bu mağduriyetin devlet tarafindan giderilmesi örnek olarak verilebilirr ${ }^{97}$. Böylece, mağdur kavramı çağdaş politika tartışmaları bakımından önem taşımaktadır. Ancak tam da bu nedenle mağdurun tanımının yapılmamasının gerektiği savunulmaktadır. Örneğin işlenen bir suç nedeniyle psikolojisi bozulan üçüncü bir kimsenin psikolojik destek gören kapsamına alınması mümkünken, faile verilecek cezanın belirlenmesinde dikkate alınmaması yerinde olacaktı ${ }^{98}$. Ancak yine de ceza hukukundaki mağdur kavramının tanımının yapılmasında fayda vardır. Bunun dışında örneğin sosyal devlet ilkesi gereğince suçtan etkilenen kişilere yardımda bulunmak isteniyorsa ve ceza hukukundaki mağdurun dışında kalan kimselerin kapsama alınması gerekiyorsa bunun için ilgili mevzuatta ayrıca "mağdur" şeklinde bir tanımlamaya gidilmemelidir. Ceza hukukundaki mağdur dahil edilmek isteniyorsa, bunun "mağdur" un yanında ayrıca gerekirse tek tek sayma yoluyla veya genel bir ifade kullanılmak suretiyle yapılması gereklidir. Aksi halde yukarıda bahsedildiği üzere mevzuatta birden fazla mağdur tanımının yer almasıyla karşı karşıya kalınmakta ve bu da uyumsuzluğa neden olmaktadır.

İşlenen bir suçun birden fazla kimseye zarar vermesi söz konusu olabilir. Bu kapsamda, failin fiilinden dolayı herhangi bir şekilde zarar gören herkesin mağdur olabileceği savunulmaktadı99. Örneğin "hırsızlı"" suçunun gerçekleşmesi halinde, yalnızca taşınır malın zilyedi değil, taşınır malın zilyedinin alacaklılarına da zarar verilir. Gerçekleştirilen suç nedeniyle çeşitli şekillerde zarara uğrayan herkesin mağdur olarak kabul edilmesiyse, mağdur kavramının kapsamının genişlemesine neden olur ${ }^{100}$. Adeta birbirlerini içine alan halkalar gibi çekirdek halka örneğin "kasten öldürme" suçunda ölen, bir sonraki halka ölenin ailesi, bir sonraki halka ölen kişinin kaybından önemli ölçüde etkilenen yakın çevre, bir sonraki halkaysa söz konusu suçun haberini yapan gazeteci, haberi televizyonda izleyen izleyici, hatta failin fiili nedeniyle failin ailesi, yakın arkadaşları ve çevresinden oluşacaktır. Zira bu halkalar içinde yer alan her bir kimse, işlenen suçtan etkilenmektedir. Mağdurun geniş anlaşılması halinde tüm bu sayılan kimseler mağdur olarak kabul edilir. Mağdur" kavramını bu şekilde genişletmek "kasten öldürme" suçu neticesinde ölen kişiyle, bu kişinin yakınlarını ve hatta güvenlik kaygısıyla gece uykusu kaçan komşusunu bir tutmak anlamına gelecek ve bu durum adil olmayacağı gibi rahatsız edici bir eşdeğerliğe neden olacaktır ${ }^{101}$. Hemen hemen herkes herhangi bir şeyin mağduru olabilecektir ${ }^{102}$. Yine şayet herkes mağdursa artık mağdurun bulunmadığını söylemek dahi

\footnotetext{
${ }^{93}$ LIU, s.123, 125-126.

${ }^{94}$ BENTHAM, Jeremy: The Works of Jeremy Bentham, V.1 (Principles of Morals and Legislation, Fragment on Government, Civil Code, Penal Law), 1843, s.58-59.

${ }^{95}$ LIU, s.115.

${ }^{96}$ AKBULUT, Berrin: Ceza Hukuku Genel Hükümler, 5.Bası, Ankara 2018, s.375.

${ }^{97}$ VON HIPPEL, Eike: "Staatliche Entschädigung für Verbrechensopfer", ZRP, (1), 1971, s.5.

${ }^{98}$ LIU, s. 175.

${ }^{99}$ LIU, s.146.

${ }^{100}$ KATOĞLU, 659

${ }^{101}$ LIU, s.120, 129-130.

102 BAYLEY, s.53.
} 
mümkün hale gelecektir ${ }^{103}$. Ancak bir suç nedeniyle mağdur olmak kendine has özellikleri olan bir deneyim olup ${ }^{104}$ bu durumda ceza hukukunda mağdurdan bahsetmek gereklidir.

Suçun mağdurunu ifade etmek için suçtan doğrudan doğruya etkilenen anlamında suçun "pasif süje"si deyimine yer verilmesi ${ }^{105}$ dahi, mağdurun pasifize edildiğinin bir göstergesi olarak yorumlanabilir ${ }^{106}$. Zira çaresizlik ve de suçtan etkilenenlerin pasifliği ifade edilmektedir ${ }^{107}$. Nitekim mağdur haklarının son yıllara değin revaçta olmaması bu kapsamda değerlendirilmelidir ${ }^{108}$.

Suçla ihlal edilen, ceza müeyyidesiyle korunan varlık veya menfaatler maddi anlamda hukuka aykırrlığı oluşturmakla beraber suçun hukuki konusunu da oluşturur. Ceza hukukunda, suçun hukuki konusundan hareketle suçun mağduru belirlenmelidir. $\mathrm{Bu}$ kapsamda suçun mağduru, suçun hukuki konusunun hamili yani taşıyıcısi ${ }^{109}$ veya sahibidir ${ }^{10}$. Ancak burada mağdurla suçun özel mağduru kast edilmektedir. Nitekim doktrinde her ne kadar üzerinde birlik sağlanamamış olsa da suçun genel ve özel mağduru olmak üzere ikili bir ayrımın yapıldığı görülmektedir.

Devlet, bir suçun işlenmemesi bakımından bireyin veya genel olarak toplumun çıkarından farklı bir çıara sahiptir. Söz konusu farklılık, cezai korumanın konusundan kaynaklanır. Zira cezai korumanın konusunu, devletin ihlal edilmeleri yalnızca ceza müeyyidesiyle mümkün sosyal bir zarara sebebiyet verdiği kabul edilen esash varlıkların muhafazasında veya suç olarak öngörülen fiillerin ortaya çıardığı tehlikeye karşı toplumun savunulmasındaki menfaat oluşturur. $\mathrm{Bu}$, devletin ortak hayat şartlarını garanti altına alma konusundaki menfaatidir. Bu menfaat genel bir menfaat olup, kendisine göre doğrudan doğruya korunan varlık veya menfaatlerin himayesiyle ilgilidir. Suç işlendiğinde devletin bu himayeye ilişkin menfaati zedelenmektedir ${ }^{111}$. Nitekim gerçekleştirilen her bir suç, dolaylı da olsa devlete ait kamusal nitelikteki devletin varlığılla, gelişmesine ve devamına ${ }^{112}$ ilişkin menfaatin ihlali şeklindeki genel menfaatin ihlalidir ${ }^{113}$. Toplumsal düzene zarar veren fiillerin belirlenmesi ve cezalandırılması kamu düzeninin bir gereğidir. Hukuk düzeninin korunmasının bizatihi kendisinin hukuki konuyu ${ }^{114}$ mu yoksa cezai korumanın konusunu mu oluşturduğuysa doktrinde tartışmalıdır ${ }^{15}$. Ancak hangi görüş benimsenirse benimsensin devlet, suçun işlenmemesine ilişkin genel kamusal menfaatin sahibi ${ }^{116}$ veya hamilidir ve bu nedenle mağdurudurr ${ }^{117}$. Bu nedenle her suçun biri devamlı, doğal ${ }^{118}$, daimî, zorunlu yani her suç için ortak olan genel ${ }^{119}$, diğeri ise özel yani suçtan suça değişebilen olmak üzere iki ayrı mağduru bulunmaktadır ${ }^{120}$. Kriminologlar, viktimologlar ve hukuk teorisyenlerince mağdur, devletin muhakemedeki ve infazdaki egemenliği nedeniyle adalete katılma hakkından mahrum bırakılan, güçsüz olan taraf şeklinde tanımlanmaktaysa da mağdurun egemen devlet karşısındaki hak mücadelesi olarak görülmesi yerine mağdurun çokluğunu savunan post-modern anlayış daha yerindedir ${ }^{121}$.

\footnotetext{
${ }^{103}$ SYKES, Charles J.: A Nation Of Victim The Decay Of The American Character, New York 1992, s.18.

104 Amerika'da oldukça kilolu bir kadın, kilosu nedeniyle sürücü koltuğuna oturamaması ve sürücü belgesinin yetkililerce elinden alınması nedeniyle bedeni bakımından ayrımcılığa uğradığını ve "mağdur” olduğunu belirterek “Oprah Winfrey Şov”a katılmışsa da (bkz. SYKES, s.8) burada ayrımcılık suçunun koşulları oluşmadığı takdirde ceza hukukunda mağdurdan bahsedilemez.

105 SAATÇIOĞLU, Cemil: "Türk Ceza Kanununun Dayandığı Düşünce Temeli, Cezaların Sınıflandırlması, Suç ve Ceza Hakkında Bazı Sorunlar”, YD, 3(3-4), 1977, s.118; HAFIZOĞULLARI, Zeki/ÖZEN, Muharrem: Türk Ceza Hukuku Genel Hükümler, 12.Bası, Ankara 2019, s.373; SOYASLAN, Doğan: Ceza Hukuku Özel Hükümler (Özel), 12.Bası, Ankara 2018, s.84; YALÇIN, Türkan/KÖPRÜLÜ, Timuçin: Ceza Hukuku Genel Hükümler Uygulamalı Çalıșmalan, 6.Bası, Ankara 2019, s.157.

${ }^{106}$ BERGELSON, s.1.

107 VON MAYENBURG, s.125.

108 ÖZEK, Çetin: “Suç Mağdurunun Korunması ile İlgili Bazı Sorunlar” (“'Suç”), ï̈HFM, 50(1-4), 1984, s.15.

${ }^{109}$ VON MAYENBURG, s.122.

${ }^{110}$ MITSCH, Wolfgang: “StGB § 77 Antragsberechtigte”, Münchener Kommentar zum Strafgesetzbuch, München 2016, Band 2, Rn.4; ÖZBEK, Veli Özer/DOĞAN, Koray/BACAKSIZ, Pınar, Türk Ceza Hukuku Genel Hükümler, 10.Bası, Ankara 2019, s.211.

${ }^{111}$ EREM, Faruk/DANIŞMAN, Ahmet/ARTUK, Mehmet Emin: Ümanist Doktrin Açısından Türk Ceza Hukuku Genel Hükümler, 14.Bası, Ankara 1997, s.242; ZAFER, Hamide: Ceza Hukuku Genel Hükümler, İstanbul 2013, s.158.

112 ÖZEK, Çetin: Siyasi İktidar Düzeni ve Fonksiyonları Aleyhinde Cürümler (Siyasi), 1.Bası, İstanbul 1967, s.38.

${ }^{113}$ ERSOY, Yüksel: Ceza Hukuku Genel Hükümler, Ankara 2002, s.68-69.

114 ÜNVER, s.481.

115 Ayrntılı bilgi için bkz. TOROSLU, Cürümlerin, s.178-179.

116 ÜNVER, s.481.

${ }^{117}$ KATOĞLU, s.674; TEZCAN, Durmuș: “Mağdurun Hakları ve Tanıkların Korunması”, Ceza Hukuku Reformu, İstanbul 2001, s.73. 118 YURTCAN, Erdener: Şahsi Dava ve Uygulaması, 3.Bası, Ankara 1989, s.54.

${ }^{119}$ DÖNMEZER, Sulhi/ERMAN, Sahir: Nazari ve Tatbiki Ceza Hukuku, C.II, 1.Bası, İstanbul 2019, s.726. Mağdur kavramı yerine devletin işlenen her bir suçun zarar göreni olduğu da ifade edilmektedir. Bkz. ONURSAL, s.22.

${ }^{120}$ ÖZTÜRK Bahri/ERDEM, Mustafa Ruhan: Uygulamalı Ceza Hukuku ve Güvenlik Tedbirleri Hukuku, 19.Bası, Ankara 2019, s.200.

Genel mağdur için şekli; özel mağdur içinse asli mağdur ifadelerinin de kullanıldığı yönünde bkz. TOROSLU, Cürümlerin, s.178.

${ }^{121}$ KICHENGAST, Tyrone: The Victim in Criminal Law and Justice, 1.Bası, New York 2006, s.1.
} 
Kuramsal düzeyde kalan söz konusu tartışmaların esasında "pratik herhangi bir sonucu yoktur"122. Her bir suç bakımından değişen özel mağdurun yanında ayrıca ortak mağdurun devlet olduğunun kabulü, adeta gölgeye varlık kazandırmak anlamına geleceği ve gereksiz kelime tekrarlarına neden olacağı için eleştirilmektedir. Nitekim ceza hukukunun teorik aşırılıkları bertaraf etmesi gereklidir. Her suçun genel mağdurunun devlet olduğu kabulünün yorumcu ve uygulayıcılar bakımından önemi bulunmamaktadır ${ }^{123}$. Söz konusu görüş ne kadar yerinde olsa da bu durum tüm suçlarda genel mağdurun devlet olduğu gerçeğini değiştirmemektedir. Nitekim cezalandırma hakkının devlete ait olması, genel mağdurun devlet olduğunun ${ }^{124}$, bu kapsamda ceza hukukunun bir kamu hukuku dalı olarak kamunun menfaatlerini gözettiğinin bir göstergesidir ${ }^{125}$. Böylece af, zamanaşımı gibi kurumlarının açıklanması mümkün hale gelmektedir ${ }^{126}$. Aksinin kabulü, bahsi geçen bu hususların temelsiz kalmasına sebebiyet verir.

Özel mağdursa, hukuki konudan ve bu sayede suçun özünden hareketle sınırlandırılmalıdır. Suçun mağdurunun belirlenebilmesi için ceza normunun yorumu esnasında hukuki konunun öncelikle doğru bir şekilde belirlenmesi gereklidir ${ }^{127}$.

\section{HAYVANIN CEZA HUKUKU VASITASIYLA KORUNMASI HALINDE MAĞDURUN TESPITI SORUNU}

Nasıl ki her suçun faili varsa, mağduru da vardır ${ }^{128}$. Zira her suçun hukuki konusu vardır ve bu durum, suçla korunan hukuki varlık ya da menfaatin ait olduğu süjeyi gerekli kılmaktadır ${ }^{129}$.

Hayvanın kötü muamelelere karşı ceza hukuku vasitasıyla korunmasıyla hangi varlık veya menfaatin korunduğu sorusunu cevaplamak kolay değildir. Örneğin bir görüşe göre, insanla hayvan arasındaki ahlaki düzen korunmaktadır. Ancak, hayvan hukuken korunan varlık veya menfaatin sahibi, yani mağdur olarak kabul edilemez ${ }^{130}$. Al. MK m.90a'ya rağmen, ceza hukuku anlamında hayvanın eşya olarak kabul edilmesi gerektiği savunulmaktadır. Bu kapsamda hayvan örneğin "hırsızlı" suçunun maddi konusu olabilmektedir ${ }^{131}$. Örneğin "mala zarar verme" suçunun düzenlendiği TCK m.151/2 bakımından suçun maddi konusu "sahipli hayvan"dır. Esasında ceza hukuku, hiçbir zaman nesneleri değil, nesnelerle insan arasındaki ilişkileri korumaktadır ${ }^{132}$. Hayvanlar da bu şekilde değerlendirilmektedir ${ }^{133}$. Nitekim TCK m.142/2-g'de "hırsızlık" suçunun "büyükve küçükbaş hayvan hakkanda" işlenmesi ağırlaştırıcı neden olarak öngörülmektedir. Ancak bu hüküm bizatihi hayvanın korunmasına hizmet etmemektedir. Yine "mala zarar verme" suçu da dolaylı olarak hayvanın "canlı" olarak korunmasını sağlamaktadır, zira "mülkiyet" korunmak istenmektedir. Malikin hayvanla ilgili olarak umduğu değeri yok etmesi veya azaltması nedeniyle cezalandırma söz konusudur ${ }^{134}$. Mağdursa hırsızlık suçunda zilyet ${ }^{135}$, mala zarar verme suçunda maliktir ${ }^{136}$.

Hayvan bizatihi mağdur olmasa da insanın, toplumun, devletin veya uluslararası toplumun hayvana ilişkin menfaati yahut hakkı, suçun hukuki konusunu oluş̧urabilirr ${ }^{137}$. Hukuk düzeninin hayvanlara karşı

\footnotetext{
122 KATOĞLU, s.675-676. Her normla korunmak istenen hukuki konunun sahibinin ya da taşıyıcısının sayıca bir olacağı, devletin yanında bireyin de mağdur olduğundan bahsedilemeyeceği yönündeki görüş için bkz. ÜNVER, s.482.

123 TOROSLU, Cürümlerin, s.177.

124 Genel-özel mağdur ayrımını kabul etmekle birlikte genel mağdurun devlet olmayıp toplum olduğu da savunulmaktadır. Bkz. ÖZGEN, Eralp: Ceza ve Ceza Muhakemesi Hukuku Bilgisi, Eskişehir 1988, 3. Çağdaş ve demokratik ceza hukuku sistemlerinde bir fiilin suç haline getirilmesinin, devlet için değil toplum için yapıldığı belirtilmektedir. Bkz. PERŠAK, Nina: "Criminal Law, the Victim and Community: The Shades of 'We' and the Conceptual Involvement of Community in Contemporary Criminal Law Theory", Criminal Law and Philosophy, January 2014, 8(1), s.209. Toplumun genel mağdur olamayacağı esasında burada toplumu oluşturan herkesin (bkz. ARTUK, Mehmet Emin/GÖKCEN, Ahmet/ALŞAHIN, M. Emin/ÇAKIR, Kerim: Ceza Hukuku Genel Hükümler, 12.Bası, Ankara 2018, s.314) bir başka deyişleyse toplumu oluşturan her bir bireyin genel mağdur olduğu da doktrinde ileri sürülmektedir. Bkz. ÖZGENÇ, İzzet: Türk Ceza Kanunu Gazi Şerhi, 1.Bası, Ankara 2005, s.227.

${ }^{125}$ DÖNMEZER, Sulhi: “Devlet ve Suç Mağduru İlişkisi”, Onar Armağanı, İstanbul 1977, s.184.

${ }^{126}$ HAFIZOĞULLARI, Zeki:“5237 Sayll Kanunun 43/1. Maddesine 2005/5377 Sayll Kanunla Eklenen 'Mağduru Belli Bir Kişi Olmayan Suçlarda Da Bu Fıkra Hükmü Uygulanır’ Hükmü Hakkında”, Ord. Prof. Dr. Sulhi Dönmezer Armağanı, C.II, Ankara 2008, s.861.

${ }^{127}$ KATOĞLU, s.661.

128 ÖZGENÇ, İzzet, Türk Ceza Hukuku Genel Hükümler, 13.Bası, Ankara 2017, s.208; KOCA, Mahmut/ÜZÜLMEZ, İhan: Türk Ceza Hukuku Genel Hükümler, 12.Bas1, Ankara 2019, s.114; YÜCEL, Mustafa Tören: Suç ve Ceza Anatomisi, Ankara 1973, s.134.

129 TOROSLU, Cürümlerin, s.200.

130 PFOHL, Michael: Münchener Kommentar zum Strafgesetzbuch, Band 6, München 2018, TierSchG § 17, Rn.1-6; KÖNİ, Burhanettin: Ceza Hukuku Ders Notları, Ankara 1956-1957, s.75.

${ }^{131}$ BOCK, Dennis: Strafrecht Besonderer Teil 2, 1.Bası, Berlin 2018, s.8; KÜPER, Wilfried: “Die „Sache mit den Tieren“ oder: Sind Tiere strafrechtlich noch ,Sachen“?”, Juristen Zeitung, (9), 1993, s.438.

132 GÜNGÖR, Devrim: Resmî Belgelerde Sahtecilik Suçu, 1.Bası, Ankara 2010, s.22.

${ }^{133}$ BLOY, Ren: "Die Straftaten gegen die Umwelt im System des Rechtsgüterschutzes", ZStW 100(3), 1988, s.490.

${ }^{134}$ KÜPER, s.438.

135 TOROSLU, Özel, s.135. "Hırsızlık” suçunun hukuki konusunun zilyetlik olmayıp mülkiyet olduğu (bkz. OPPENHEIM, L.: Die Objekte des Verbrechens, Basel 1894, s.270) bu nedenle mağdurun malik olduğu yönünde bkz. ÖZGENÇ, Gazi, s.225.

${ }^{136}$ DÖNMEZER/ERMAN, s.730.

137 TOROSLU, Cürümlerin, s.161.
} 
gerçekleştirilen olumsuz fiilleri ceza yaptırımına bağlamasındaki amacı, bu fiillerin toplumda uyandırdığı tepkininin önlenmesini ve bir daha tekrar edilmemesini sağlamaktır ${ }^{138}$. Ancak örneğin başkasına ait bir hayvanla cinsel ilişkiye girme ${ }^{139}$, şartları varsa "mala zarar verme" suçu kapsamında kabul edilmekteyken ${ }^{140}$, kişinin kendisine ait hayvanla ilişkiye girmesi halinde suçun failinin ve mağdurunun kim olduğu önem taşımaktadır ${ }^{141}$. Zira bir kimse bir suçun hem faili hem de mağduru olamaz ${ }^{142}$. Yani bu iki sıfat aynı kişide birleşemez ${ }^{143}$.

Sahipsiz hayvanlar bakımından da sorun devam etmektedir. Yalnızca sahipli hayvanlara değil, sahipsiz hayvanlara karşı gerçekleştirilen kötü muamelelerin de suç olarak öngörülmesi gereklidir. Zira bir hayvanın insan tarafindan nedensiz yere öldürülmesi sahipli veya sahipsiz olsun toplum açısından önem arz etmektedir ${ }^{144}$. Söz konusu durumda suçun mağduruna toplum denmesi makul gözükmektedir ${ }^{145}$. Ancak toplumun suçun mağduru olup olamayacağı hususunda doktrinde tartışmalar bulunmaktadır.

Doktrinde suçun mağdurunun kim olabileceği sorunuyla ilgili olarak üç farklı görüş bulunmaktadır. Bu görüşlerden ilkine göre yalnızca gerçek kişi suçun mağduru olabilir ${ }^{146}$. Zira hukuki konunun birey dişında kimseye ait olamayacağı ileri sürülmektedir. Bu görüsse göre her suç doğrudan doğruya ve yalnızca bireye aittir ve temelini anayasadan alan hukuki konuyu ihlal eder ${ }^{147}$. Devlet veya herhangi bir tüzel kişiyle, bireyler arasında menfaat çatışması olamaz. Hukukun, belli hukuk alanlarıyla ilgili olarak bazı hukuksal sonuçlar bağladığı oluşumların asıl amacı bireye ait hukuki konuların yaşama geçirilebilmesidir. Bu nedenle tüzel kişiler herhangi bir hukuki konunun sahibi olamaz. Lakin yasal düzenlemelerle veya yasal düzenlemelerin imkân verdiği hallerde bireylerin iradeleriyle hukuki konunun taşıyıcısı niteliğindeki oluşumlar söz konusu olabilir. Gerçek kişi dışındaki hukuken kişilik tanınan bu oluşumlar, yalnızca hukuki konusunun taşıyıcısı olup sahibi olamaz ${ }^{148}$. Bu nedenle her ne kadar söz konusu topluluklar mağdur olamasa da zarar gören olabilir denilmektedir ${ }^{149}$. İkinci görüşe göreyse sadece kişi yani gerçek ve tüzel kişi suçun mağduru olabiliir ${ }^{150}$. Ceza ilişkisi, yalnızca kişilikleri bulunan varlıklar arasında kurulabileceğinden tüzel kişiliği bulunmayan toplulukların suçun mağduru olamayacağı savunulmaktadır ${ }^{151}$. Üçüncü ve çalışmada benimsenen görüşe göreyse kişinin yanında tüzel kişiliğe sahip bulunmayan toplulukların dahi suçun mağduru olması mümkündür ${ }^{152}$. İnsan gerek bireysel gerekse diğer insanlarla toplu halde bulunmasıyla dikkate alınır. İnsanların her biri tek başına birer birey olmasına karşın, ortak bir amaç etrafinda ilişki halinde olduğu kişilerle ve içinde yer aldığı gruplarla adeta bir kümelenme içindedir ${ }^{153}$. Ancak topluluktan bahsedilebilmesi için, topluluğun hukuken tanınan sosyal bir fonksiyon görmesi ve ortak bir iradeye sahip olması (siyasi partiler, sendikalar, meslek odaları, dini topluluklar, aile gibi) gereklidir. Zira burada tesadüf eseri bir arada olan

138 VIDAL/MAGNOL, s.70.

${ }^{139}$ Her ne kadar "müstehcenlik" suçunun düzenlendiği TCK'nın 226. maddesinin 4. fikrasında "şiddet kullanılarak, hayvanlarla ... doğal olmayan yoldan yapılan cinsel davranışlara ilişkin yazı, ses veya görüntüleri içeren ürünleri üreten, ülkeye sokan, sațşa arz eden, satan, nakleden, depolayan, başkalarının kullanımına sunan veya bulunduran kişiı"nin cezalandırılacağı öngörülse de bu suç hayvanla olan cinsel ilişkiyi cezalandırmamaktadır.

140 TOROSLU, Özel, s.59.

${ }^{141} \mathrm{Bu}$ kapsamda gazete yer alan şu haberin de örnek olarak gösterilmesi mümkündür: "Muğla'nın Köyceğiz İlçesinde, bir kişi, kendisine ait olduğunu öne sürdüğü bir köpeği arabasının arkasına bağladı. Sıcak havada koşmaktan yorulan köpek, bir süre sonra kendini yere bıraktı, ancak araba durmadı. Arabanın arkasına bağlanan hayvan, kilometrelerce sürüklendi." Haber metni için bkz. https://www.cnnturk.com/video/turkiye/kopegini-arabaya-baglayip-asfalttasurukledi (Erişim: 30.06.2020)

${ }^{142}$ SOYASLAN, Doğan: Ceza Hukuku Genel Hükümler (Genel), 8.Bası, Ankara 2018, s.250.

143 AKBULUT, s.375.

${ }^{144}$ KOTTER, Ludwig: Vom Recht des Tieres, München 1966, s.5.

145 VIDAL/MAGNOL, s.70.

146 KOCA, Mahmut/ÜZÜLMEZ, İlhan “Ceza ve Ceza Muhakemesi Hukukunda Mağdurun Korunması ve Mağdura Tanınan Haklar”, HPD, (7), 2006, s.141; HAKERİ, Hakan: Ceza Hukuku Genel Hükümler, 16.Bası, Ankara 2019, s.139; YILDIZ, Ali Kemal: Ceza Muhakemesi Hukukunda Mağdur - Suçtan Zarar Gören - Şikâyetçi, 1.Bası, Ankara 2008 s.22; KOÇ, Ziya: Ceza Muhakemesinde Katılan, 1.Bası, İstanbul 2011, s.101; BIRTEK, Fatih: Ceza Hukuku Genel Hükümler Temel Bilgiler, 6.Bası, Ankara 2018, s.203.

${ }^{147}$ MURMANN, Uwe: Die Selbstverantwortung des Opfers im Strafrecht, 1.Bas1, Heidelberg 2005, s.148-149.

148 ÜNVER, s.142.

${ }^{149}$ KARAKAŞ DOĞAN, Fatma: “Suçtan Doğan Mağduriyetin Devlet Tarafindan Giderilmesi ve Suç Mağdurlarına Yardım Hakkında Kanun Tasarısı”, (“Suçtan”), TBBD, (95), 2011, s.205.

${ }^{150}$ GÓMEZ-JARA DÍEZ, Carlos: "Grundlagen des konstruktivistischen Unternehmensschuldbegriffes", ZStW 119(2), 2007, s.307; KUNTER, Nurullah: Suçun Maddi Unsurları Nazariyesi, 1.Bası, İstanbul 1955, s.118-119; ÖZBEK, Veli Özer: Ceza Hukukunda Suçtan Doğan Mağduriyetin Giderilmesi, Ankara 1999, s.26, dp.20.

${ }^{151}$ DÖNMEZER/ERMAN, s. 727.

152 PISAPIA, Gian Domenico İtalyan Ceza Hukuku Müesseseleri Genel Kısım, Padova 1965, (Çev: Atıf Akgüç), Ankara 1971, s.42; LANDAU, Simha F./FREEMAN LONGO, Robert E.: "Classifying Victims: A Proposed Multidimensional Victımological Typology", International Review of Victimology, 1990, 1, s.271.

${ }^{153}$ KATOĞLU, s.678. 
topluluklar ifade edilmemektedir ${ }^{154}$. Bireyin ve bireyin gelişimini özgürce gerçekleştirilebilmesiyle ilgili ekonomi ve çevre gibi hukuki varlık veya menfaatlerin korunmak istenmesi beraberinde toplulukların korunmasını getirmektedir ${ }^{155}$. Bu kapsamda yalnızca insanın değil, topluluğun da bazı varlık veya menfaatlerin sahibi ya da hamili olabilmesinden bahsetmek gerekmektedir. Toplulukların tüzel kişiliği bulunsun veya bulunmasın mağdur olması mümkündür ${ }^{156}$ ki toplulukların kendini mağdur olarak gördüğü suçlar da bulunmaktadır ${ }^{157}$. Ancak burada tüzel kişiliği bulunmayan topluluğun üyelerinin gerçek veya tüzel fark etmeksizin kişilerden oluşması gereklidir ${ }^{158}$. Bireyin oluşturduğu ve tüzel kişiliği bulunmayan topluluklar örneğin aile, toplum ve devletler topluluğu şeklinde ortaya çımakta ve böylece aileye, topluma ve devletler topluluğuna karşı işlenebilen suçlardan bahsetmek mümkün hale gelmektedir. Aksinin kabulü toplumsal gerçekliğin dikkate alınmaması sonucunu doğurmaktadır ${ }^{159}$. TCK'da, 765 sayılı TCK'dan farklı olarak suçların “Özel Hükümler” başlığını taşıyan “ỉkinci Kitap”ta ve suçun mağduruna göre dört kısımaltında tasnif edilmiş olması, üçüncü görüşün benimsenmesinde etkili olmaktadır. Nitekim TCK'da "Birinci Kısım"da "Uluslararası Suçlar" yani uluslararası topluğa karşı suçlar, "İkinci Kısım"da "Kişilere Karşı Suçlar", "Üçüncü Kısım"da "Topluma Karşı Suçlar", "Dördüncü Kısım”daysa "Millete ve Devlete Karşı Suçlar ve Son Hükümler"e yer verilmiştir. Her bir kısım daha sonra, hukuki konu ölçütüne başvurularak çeşitli bölümlere ayrılmıştır. Bu kapsamda TCK'nın özel kısmı bakımından kanun koyucunun suçun hukuki konusu kriterini esas aldığı ve bunu yaparken de mağduru esas alarak bir tasnif gerçekleştirdiği anlaşılmaktadır ${ }^{160}$. Lakin bu görüşlerden hangisi benimsenirse benimsensin hayvana karşı gerçekleştirilen kötü muamelelerin suç olarak düzenlenmesi halinde hayvanın mağdur olduğunu söylemek mümkün değildir.

Hayvanın mağdur olamayacağı tespitini yaptıktan sonra, bu durumda "mağduru olmayan suç" veya "mağdursuz suç" şeklinde ifade edilen ayrımdan ${ }^{161}$ bahsedilip bahsedilemeyeceği hususu üzerinde durmakta fayda vardır. Herhangi bir kimseye ait belli bir varlığın ihlal edilmediği, edilse dahi bunun kişinin kendisine ait bir varlığı üzerinde gerçekleştiğ $1^{162}$ ve devlet bakımından önem arz etmesi nedeniyle cezalandırılan fiiller bakımından "mağduru olmayan suç" kavramı kullanılmaktadır. Nitekim esasında bu suçlarda korunan hukuki varlık veya menfaatin olmadığı kabul edilmektedir ${ }^{163}$. Ancak söz konusu ayrımın esasında yapay olduğu ifade edilmelidir. Nitekim bu ayrımın "hukuki konusu olmayan suçlar" varsayımını temel aldığı anlaşılmaktadır. Bu görüşü kabul edenler, içlerinde kamusal menfaatleri tehdit eden bazı tehlike suçlarının da bulunduğu suçlar bakımından belli bir kişiye ait varlık ya da menfaatin bulunmadığını da belirtmektelerdir ${ }^{164}$. Ancak bir suç tanımına gidildiğinde çeşitli varlık ya da menfaatlerin korunması amacı vardır. Suçla korunan varlı ya da menfaatin ihlal edilmesi suçun özünü oluşturur ve söz konusu ihlal gerçekleşmediği takdirde suçtan bahsedilemez ${ }^{165}$. Zira hukuki konusu ve mağduru bulunmayan suç bulunmamaktadır ${ }^{166}$. Söz konusu durumu ifade etmek ve esasında "mağdursuz suç" olmayacağı için ${ }^{167}$, doktrinde "mağdurun kolektifliği" ya da "mağdurun anonimliği"nden de bahsedilmektedir ${ }^{168}$. Bu nedenle "mağduruz suç" kavramı ceza hukukunda geçerli kabul edilmemelidir ${ }^{169}$. Bu kapsamda hayvanlara karşı gerçekleştirilen kötü muamelelerin suç olarak öngörülmesi halinde bu suçun "mağdursuz suç" olduğu söylenemez.

\section{SONUÇ}

HKK'da hayvanlara karşı gerçekleştirilen pek çok olumsuz nitelikteki fiil, ceza hukuku anlamında suç olarak öngörülmese de karşllığında idari yaptırımın öngörüldügü kabahat olarak düzenlenmiştir. Örneğin HKK m.14/1-j'de "Hayvanlarla cinsel ilişkide bulunmak, işsence yapmak" yasak olarak düzenlenmiş olup bu yasağı çiğnemenin yaptırımıysa m.28/1-k' da “üçyüz Türk Lirası”'idari para cezası olarak öngörülmektedir. Ceza hukukunun son araç olma niteliği bakımından doğru bir tercih yapıldığı söylenebilirse de hayvanlara karşı gerçekleştirilen söz konusu fiillerin önlenmesi bakımından gereken yeterlilik sağlanamamaktadır. Bu

\footnotetext{
${ }^{154}$ HIRSCH, Hans Joachim: Ehre und Beleidigung, Karlsruhe 1967, s.101-102.

155 ÜNVER, s.1016.

${ }^{156}$ MANNHEIM, Hermann: Comparative Criminology, V.2, 2.Bas1, London 1965, 673.

${ }^{157}$ SYKES, s.XII.

${ }^{158}$ Nitekim ceza kanununun kişiler arasında uygulanma kabiliyetine sahip olduğu yönünde bkz. AYGÜN EŞiTLLI, Ezgi: “Hukuka Aykırı Hayvan Deneyleri', HHFD, 2(12), 2012, s.21.

${ }^{159}$ TOROSLU, Cürümlerin, s.184, 305-307.

160 TOROSLU, Özel, s.18.

${ }^{161}$ LIU, s.128.

162 WERTHEIMER, Alan: “Victimless Crimes”, Ethics, 87(4), 1977, s.305.

${ }^{163}$ ROXIN, Claus: Strafrecht Allgemeiner Teil, Band I, 4.Basi, München 2006, s.18.

${ }^{164}$ KATOĞLU, s.682.

${ }^{165}$ ANDROULAKIS, Nikolaos K.: “Über den Primat der Strafe”, ZStW, 108(2), 1996, s.302.

${ }^{166}$ KATOĞLU, s.682; KOÇ, s.97.

${ }^{167}$ BAURMANN/SCHÄDLER, s.27, dp.33.

${ }^{168}$ KAISER, Günther/SCHÖCH, Heinz: Kriminologie - Jugendstrafrecht Strafvollzug, 4.Basi, München 1994, s.148.

${ }^{169}$ ÖZEK, "Suç”, s.27.
} 
nedenle hayvanlara karşı gerçekleştirilen kötü muamelelerin suç olarak öngörülmesi yerinde bir tercih olacaktır. Böylece hayvanların korunması, hayvanlara karşı gerçekleştirilen kötü muamelelerle daha etkin bir şekilde mücadele edilmesi ve caydırıcılık sağlanacaktır.

HKK'da ve TCK'da gerçekleştirilmek istenen değişikliklerle sahipli ya da sahipsiz olması fark etmeksizin hayvanlara karşı gerçekleştirilen kötü muameleler suç olarak öngörülmektedir. Hatta sahibi tarafindan hayvana karşı gerçekleştirilen kötü muameleler de bu kapsamda değerlendirilmek istenmektedir. Ancak bu tercih yürürlüğe girdiğinde, yine de hayvan suçun mağduru olarak kabul edilemez.

Hayvanın "eșya" olarak görülmesi, toplumun hayvanlara karşı beslediği duygusuyla örtüşmemektedir. Bu kapsamda "kişis" olmayan ancak "şey” de olmayan kendine özgü ama yine de hukukun objesi olmaya devam eden "üçüncü bir kategori" olarak görülmektedir. Nitekim "İsviçre Medeni Kanunu" m.641a ve Al. MK m.90a ile hayvanların eşya olmadığı ancak özel bir düzenleme olmadığı sürece eşyalara ilişkin hükümlere tabi olduğu belirtilmektedir. Hayvanın eşya olduğunun kabul edilmemesi halinde eşyaya ilişkin hükümler hayvanlara eşya olduklanı için değil ancak eşya gibi sayıldıklanı için uygulanmaktadır. Bu kapsamda Türk hukuk sisteminde de benzer bir düzenlemeye yer verilmesi gelecek için izlenebilecek yerinde bir tercih olarak kabul edilmelidir. Ancak benzer düzenlemeye Türk hukuk sisteminde yer verilmesi, yine de hayvanın suçun mağduru olmasına imkân vermeyecektir.

Ceza ve ceza muhakemesi hukuku bakımından doğurduğu sonuçlar dikkate alındığında, mağdur kavramının sınırlarının çizilmesi önemli bir ihtiyaç olarak ortaya çıkmaktadır. Bu kapsamda malvarlı̆̆ına karşı suçlar ayrı tutulmak kaydıyla hayvanın kötü muamelelere karşı ceza hukuku vasıtasıyla korunması halinde doktrinde her ne kadar toplumun mağdur olup olamayacağı hususunda tartışmalar bulunmaktaysa da toplumun mağdur olarak kabulü gereklidir. Zira hayvanların korunması, gelecek kuşaklara sağlıklı bir şekilde aktarılması gerekli olup buna ilişkin menfaat topluma aittir. Nitekim TCK m.181/4'te "çevrenin kasten kirletilmesi" suçunun "insan veya hayvanlar açısından tedavisi zor hastalıkların ortaya çıkmasına, üreme yeteneğinin körelmesine, hayvanların veya bitkilerin doğal özelliklerini değiş̧tirmeye neden olabilecek niteliklere sahip olan attk veya arthklarla ilgili olarak işlenmesi" suç olarak öngörülmüştür. Benzer düzenlemeye TCK m.182/2'de "çevrenin taksirle kirletilmesi" suçunda da yer vermiş olup, her iki suçta da mağdur hayvan olmayıp toplumdur. Nitekim bu iki suç TCK'nın “Özel Hükümler”inin düzenlendiği “'ikinci Kitabı"nın “Topluma Karşı Suçlar” başlıklı “Üçüncü Kısmı”nda düzenlenmiştir ve mağdura göre yapılan söz konusu tasniften bu sonuca varılması mümkündür. Zira kanun koyucu bu suçlarla toplumun, hayvanların sağlığına ilişkin menfaatini korumak istemektedir. 
KAYNAKÇA

AÇIKGÖZOĞLU, Muhammet: Ceza Hukuku Açısından Teori ve Uygulamada Mağdur Kavramı, 1.Bası, Ankara 2000. AERTSEN, Ivo: "Karşılaştırmalı Avrupa Ülkeleri Mağdur Hakları Mevzuatı Türkiye'de Mağdur Haklarının ve Mağdurlara Verilen Hizmetlerin Güçlendirilmesi: Etkin Uygulamaya Doğru”, Uluslararası Mağdur Hakları Sempozyumu, 30-31 Ekim Ankara 2014, s.77-117.

AKBULUT, Berrin: Ceza Hukuku Genel Hükümler, 5.Bas1, Ankara 2018.

AKDEMIR, Süleyman: Ceza Hukukunda Mağdurun Korunması, İstanbul Üniversitesi Sosyal Bilimler Enstitüsü Hukuk Fakültesi Kamu Hukuku Bölümü Ceza ve Ceza Usul Hukuku Anabilim Dalı, Yayınlanmamış Doktora Tezi, İstanbul 1984.

ANDROULAKIS, Nikolaos K.: “Über den Primat der Strafe”, ZStW, 108(2), 1996, s.300-332.

ARTUK, Mehmet Emin/GÖKCEN, Ahmet/ALŞAHIN, M. Emin/ÇAKIR, Kerim: Ceza Hukuku Genel Hükümler, 12.Bas1, Ankara 2018.

ASLI, Mehrdad Rayejian: "Iranian Criminal Justice System in Light of International Standards Relating to Victims", European Journal of Crime, Criminal Law and Criminal Justice, 14(2), 2006, s.185-207.

ATAAY, Aytekin: Şahıslar Hukuku Birinci Yarım Giriş-Hakiki Şahıslar, 2.Bası, İstanbul 1969.

AYGÜN EŞiTLİ, Ezgi: “Hukuka Aykırı Hayvan Deneyleri”, HHFD, 2(12), 2012, s.16-24.

AYVERDİ, İlhan: Misalli Büyük Türkçe Sözlük, C.2, 4.Bası, İstanbul 2011.

BAURMANN, Michael C./SCHÄDLER, Wolfram: Das Opfer nach der Straftat - seine Erwartungen und Perspektiven, Eine Befragung von Betroffenen zu Opferschutz und Opferunterstützung sowie ein Bericht über vergleichbare Untersuchungen, Wiesbaden 1999.

BAYLEY, James E.: "The Concept of Victimhood", To Be A Victim Encounters With Crime And Injustice, New York 1991, s.53-62.

BENTHAM, Jeremy: The Works of Jeremy Bentham, V.1 (Principles of Morals and Legislation, Fragment on Government, Civil Code, Penal Law), 1843.

BERGELSON, Vera: Victims' Rights and Victims' Wrongs Comparative Liability in Criminal Law, 1.Bası, California 2009.

BİRTEK, Fatih, Ceza Hukuku Genel Hükümler Temel Bilgiler, 6.Bası, Ankara 2018.

BLOY, Rene: “Die Straftaten gegen die Umwelt im System des Rechtsgüterschutzes”, ZStW 100(3), 1988, s.485-507.

BOCK, Dennis: Strafrecht Besonderer Teil 2, 1.Bası, Berlin 2018.

BRIENEN, Marion Eleonora Ingeborg/HOEGEN, Ernestine Henriette: Victims of crime in 22 European criminal justice systems: The implementation of Recommendation (85) 11 of the Council of Europe on the Position of the Victim in the Framework of Criminal Law and Procedure, Nijmegen 2000.

BYDLINSKI, Franz: 'Die "Person" im Recht”, Festchrift Peter Doralt zum 65. Geburtstag, Wien 2004, s.77-94.

DEĞİRMENCİ, Olgun: “Ceza ve Ceza Muhakemesi Hukukunda Mağdur Hakları”, TBBD, (77), 2008, s.33-86.

DEMIRBAŞ, Timur: Ceza Hukuku Genel Hükümler, 14.Bası, Ankara 2019.

DEVELLIOĞLU, Ferit: Osmanlıca - Türkçe Ansiklopedik Lugat, 31.Bası, Ankara 2015.

DİNLER, Veysel: “Mağduriyet Kavramına Çok Yönlü Yaklaşım”, Suç Mağdurları, Ankara 2006, s.49-71.

DÖNMEZER, Sulhi: “Devlet ve Suç Mağduru İlişkisi”, Onar Armağanı, İstanbul 1977, s.179-191.

DÖNMEZER, Sulhi/Erman, Sahir: Nazari ve Tatbiki Ceza Hukuku, C.II, 1.Bası, İstanbul 2019.

DÖRNER, Heiner: Nomos Kommentar, Bürgerliches Gesetzbuch Handkommentar, Baden-Baden 2019, Rn.1-6.

DURAL, Mustafa: Türk Medeni Hukukunda Gerçek Kişiler, 3.Bası, İstanbul 1987.

EDWARDS, Ian: “An Ambiguous Participant, The Crime Victim and Criminal Justice Decision-Making”, The British Journal of Criminology, 44(6), 2006, s.967-982.

ERBS, George/KOHLHAAS, Max/STÖCKEL, Heinz/Müller-Walter, Markus H.: Strafrechtliche Nebengesetze, München 2018.

EREM, Faruk/DANIŞMAN, Ahmet/ARTUK, Mehmet Emin: Ümanist Doktrin Açısından Türk Ceza Hukuku Genel Hükümler, 14.Bası, Ankara 1997.

ERSOY, Yüksel: Ceza Hukuku Genel Hükümler, Ankara 2002.

FISCHER LESCANO, Andreas: "Natur als Rechtspersonen”, Zeitschrift für Umweltrecht, 2018(5)4, s.205-217.

FLETCHER, George P.: Basic Consepts of Criminal Law, 1.Bası, New York 1998.

GÓMEZ-JARA DÍEZ, Carlos: "Grundlagen des konstruktivistischen Unternehmensschuldbegriffes", ZStW 119(2), 2007, s.290-333.

GRIFFIN, John Brian: “Participation of The Public and Victims in Criminal Justice Adriministration”, UNAFEI Resource Material Series No:56, Fuchu, Tokyo, Japan 2000, s.28-47.

GUTZWILLER, Max: “Das Recht der Verbandspersonen”, Schweizerisches Privatrecht, Band II, Basel 1967, s.427-513.

GÜNGÖR, Devrim: Resmî Belgelerde Sahtecilik Suçu, 1.Bası, Ankara 2010.

GÜRKAN, Ülker: ‘Kişilik Kavramının Evrimi”, Prof. Dr. Hamide Topçuoğlu’na Armağan, Ankara 1995, s.39-54.

HAFIZOĞULLARI, Zeki/ÖZEN, Muharrem: Türk Ceza Hukuku Genel Hükümler, 12.Bası, Ankara 2019.

HAFIZOĞULLARI, Zeki: “5237 Sayılı Kanunun 43/1. Maddesine 2005/5377 Sayılı Kanunla Eklenen 'Mağduru Belli

Bir Kişi Olmayan Suçlarda Da Bu Fıkra Hükmü Uygulanır’ Hükmü Hakkında”, Ord. Prof. Dr. Sulhi Dönmezer Armağanı, C.II, Ankara 2008, s.859-865.

HAKERİ, Hakan: Ceza Hukuku Genel Hükümler, 16.Bası, Ankara 2019.

HATEMI,, Hüseyin/OĞUZTÜRK, Burcu Kalkan: Kişiler Hukuku(Gerçek Kişiler-Tüzel Kişiler), 1.Bası, İstanbul 2014. 
HAUSHEER, Heinz/AEBI MÜLLER, Regina E.: Das Personenrecht des Schweizerischen Zivilgesetzbuches, Bern 2005.

HELLMANN, Uwe: Strafprozeßrecht, Berlin Heidelberg 1998.

HELVACI, Serap: Gerçek Kişiler, 6.Bası, İstanbul 2016.

HIRSCH, Hans Joachim: Ehre und Beleidigung, Karlsruhe 1967.

İMRE, Zahit: Medeni Hukuka Giriş, 3.Bası, İstanbul 1980.

KAFES, Veli: “Ceza Hukukunda Mağdurun Zararının Giderilmesi”, AÜHFD, 60(1), 2011, s.83-116.

KAISER, Günther/SCHÖCH, Heinz: Kriminologie - Jugendstrafrecht Strafvollzug, 4.Bas1, München 1994.

KANAR, Mehmet: Osmanlı Türkçesi Sözlüğ̈̈, C.2, 1.Bası, İstanbul 2009.

KARAKAŞ DOĞAN, Fatma: "Suçtan Doğan Mağduriyetin Devlet Tarafindan Giderilmesi ve Suç Mağdurlarına Yardım Hakkında Kanun Tasarısı", TBBD, (95), 2011, s.197-234.

KATOĞLU, Tuğrul: “Ceza Hukukunda Suçun Mağduru Kavramının Sınırları", AÜHFD, 61(2), 2012, s.657-693.

KAZAKER, Gözde: Kamu Davasına Katılma, 1.Bası, Ankara 2019.

KELSEN, Hans: General Theory of Law and State, (Çev: Anders Wedberg), Cambridge 1949.

KICHENGAST, Tyrone: The Victim in Criminal Law and Justice, 1.Bası, New York 2006.

KNORRE, Hedwig V.: Das Erste Grosse BetrugsOpfer Buch, 2.Bas1, Berlin 2014.

KOCA, Mahmut/ÜZÜLMEZ, İlhan: "Ceza ve Ceza Muhakemesi Hukukunda Mağdurun Korunması ve Mağdura Tanınan Haklar" (“Ceza”), HPD, (7), 2006, s.140-149.

KOCA, Mahmut/ÜZÜLMEZ, İlhan: Türk Ceza Hukuku Genel Hükümler (Genel), 12.Bası, Ankara 2019.

KOÇ, Ziya: Ceza Muhakemesinde Katılan, 1.Bası, İstanbul 2011.

KOSHAKER, Paul/AYITER, Kudret, Modern Özel Hukuka Giriş Olarak Roma Özel Hukukunun Ana Hatları, Ankara 1977.

KOTTER, Ludwig: Vom Recht des Tieres, München 1966.

KÖNI, Burhanettin: Ceza Hukuku Ders Notları, Ankara 1956-1957.

KUNTER, Nurullah: Suçun Maddi Unsurları Nazariyesi, 1.Bası, İstanbul 1955.

KÜPER, Wilfried: “Die „Sache mit den Tieren“ oder: Sind Tiere strafrechtlich noch „Sachen“?”, Juristen Zeitung, (9), 1993, s.435-441.

LANDAU, Simha F./FREEMAN LONGO, Robert E.: "Classifying Victims: A Proposed Multidimensional Victımological Typology”, International Review of Victimology, 1990, 1, s.267-286.

LIBERMAN, Anatoly: An Analytic Dictionary Of English Etymology, Minnesota 2008.

LIU, Jessie K.: "Victimhood", Missouri Law Review, 71(1), 2006, s.115-175.

MAĞDUR HAKLARI DAİRE BAŞKANLIĞI, Yurt Dışı İnceleme ve Çalışma Ziyareti Raporları, Ankara 2016.

MANNHEIM, Hermann: Comparative Criminology, V.2, 2.Bası, London 1965.

MICHEL, Margot: "Tierschutzgesetzgebung im Rechtsvergleich: Konzepte und Entwicklungstendenzen", Animal Law - Tier und Recht Developments and Perspectives in the 21st Century Entwicklungen und Perspektiven im 21. Jahrhundert, Zürich 2012, s.593-624.

MITSCH, Wolfgang: "StGB § 77 Antragsberechtigte”, Münchener Kommentar zum Strafgesetzbuch, München 2016, Band 2.

MURMANN, Uwe: Die Selbstverantwortung des Opfers im Strafrecht, 1.Bası, Heidelberg 2005.

NIŞANYAN, Sevan: Sözlerin Soyağacı, 3.Bası, İstanbul 2007.

OĞUZMAN, M. Kemal/SELIÇi Özer/OKTAY ÖZDEMIR, Saibe: Eşya Hukuku, 20.Bası, İstanbul 2017.

ONURSAL, Sami: Kamu Davasına Müdahale, 1.Bası, İstanbul 1968.

OPPENHEIM, L.: Die Objekte des Verbrechens, Basel 1894.

ORAL, Tuğçe: "Veteriner Hekimin Sözleşme Dış1 Sorumluluğu”, TAAD, Y11:5, (16), 2014, s.319-335.

ÖZBEK, Veli Özer: Ceza Hukukunda Suçtan Doğan Mağduriyetin Giderilmesi, Ankara 1999.

ÖZBEK, Veli Özer/DOĞAN, Koray/BACAKSIZ, Pınar, Türk Ceza Hukuku Genel Hükümler, 10. Bs. Ankara 2019.

ÖZEK, Çetin: "Suç Mağdurunun Korunması ile İlgili Bazı Sorunlar" ("'Suç”), IÜHFM, 50(1-4), 1984, s.13-67.

ÖZEK, Çetin: Siyasi İktidar Düzeni ve Fonksiyonları Aleyhinde Cürümler (Siyasi), 1.Bası, İstanbul 1967.

ÖZGEN, Eralp: Ceza ve Ceza Muhakemesi Hukuku Bilgisi, Eskişehir 1988.

ÖZGENÇ, İzzet: Türk Ceza Hukuku Genel Hükümler (Genel), 13.Bası, Ankara 2017.

ÖZGENÇ, İzzet: Türk Ceza Kanunu Gazi Şerhi (Gazi), 1.Bası, Ankara 2005.

ÖZTÜRK Bahri/ERDEM, Mustafa Ruhan: Uygulamalı Ceza Hukuku ve Güvenlik Tedbirleri Hukuku, 19.Bası, Ankara 2019.

PAMUK, Gülfem: Türk ve Fransız Ceza Muhakemesi Hukuku’nda Mağdurun Makam Olarak Yeri, 1.Bası, İstanbul 2012.

PERŠAK, Nina: "Criminal Law, the Victim and Community: The Shades of 'We' and the Conceptual Involvement of Community in Contemporary Criminal Law Theory”, Criminal Law and Philosophy, January 2014, 8(1), s.205-215.

PFOHL, Michael: Münchener Kommentar zum Strafgesetzbuch, Band 6, München 2018.

PISAPIA, Gian Domenico İtalyan Ceza Hukuku Müesseseleri Genel Kısım, Padova 1965, (Çev: Atıf Akgüç), Ankara 1971.

RICHTER, Dagmar: “Recht Des Tieres und Menschliche Interessen”, Menschen Rechts Magazin, (2), 2015, s.97-106. ROXIN, Claus: Strafrecht Allgemeiner Teil, Band I, 4.Bası, München 2006. 
SAATÇiOĞLU, Cemil: "Türk Ceza Kanununun Dayandığı Düşünce Temeli, Cezaların Sınıflandırlması, Suç ve Ceza Hakkında Bazı Sorunlar", YD, 3(3-4), 1977, s.113-126.

SEROZAN, Rona: Taşııır Eşya Hukuku, 2.Bası, Ankara 2007.

SiRMEN, Lale: Eşya Hukuku, 1.Bası, Ankara 2013.

SOKULLU AKINCI, Füsun/Dursun, Selman: Viktimoloji (Mağdurbilim), 3.Bası, İstanbul 2016.

SOYASLAN, Doğan: Ceza Hukuku Genel Hükümler (Genel), 8.Bası, Ankara 2018.

SOYASLAN, Doğan: Ceza Hukuku Özel Hükümler (Özel), 12.Bası, Ankara 2018.

STUCKI, Saskia: “Rechtstheoretische Reflexionen zur Begründung eines tierlichen Rechtssubjekts”, Animal Law - Tier und Recht Developments and Perspectives in the 21st Century Entwicklungen und Perspektiven im 21. Jahrhundert, Zürich 2012, s.143-172.

SUNGURBEY, İsmet: Hayvan Hakları, İstanbul 1992.

SYKES, Charles J.: A Nation Of Victim The Decay Of The American Character, New York 1992.

ŞAHIN, Cumhur/GÖKTÜRK, Neslihan: Ceza Muhakemesi Hukuku-I, 10.Bası, Ankara 2019.

TANER, Tahir: Ceza Hukuku Umumi Kısım, 3.Bası, İstanbul 1953.

TEZCAN, Durmuş: "Mağdurun Hakları ve Tanıkların Korunması”", Ceza Hukuku Reformu, İstanbul 2001, s.73-84.

TOROSLU, Nevzat: Ceza Hukuku Özel Kısım (Özel), Ankara 2019.

TOROSLU, Nevzat: Cürümlerin Tasnifi Bakımından Suçun Hukuki Konusu, 1.Bası, Ankara 1970.

TRULSON, Chad R.: "Victims' Rights and Services: Eligibility, Exclusion, And Victim Worth", Reaction Essay, 4(2), 2005, s.399-414.

TÜRKÇE SÖZLÜK: Türk Dil Kurumu, 11.Bası, Ankara 2011.

TÜRK HUKUK LÜGATI: Türk Hukuk Kurumu, 3.Bası, Ankara 1991.

TÜRKIYE BÜYÜK MILLET MECLISİ İNSAN HAKLARINI İNCELEME KOMISYONU, Mağdur Hakları İnceleme Raporu, 24. Dönem, 4. Yasama Yllı 2014.

UMUR, Ziya: Roma Hukuku, Tarihi Giriş-Kaynaklar-Umumi Mefhumlar-Hakların Himayesi, İstanbul 1982.

ÜNVER, Yener: Ceza Hukukuyla Korunması Amaçlanan Hukuksal Değer, 1.Bası, Ankara 2003.

VELIDEDEOĞLU, Hıfzı Veldet: Türk Medeni Hukuku, C.I, Umumi Esaslar, 6.Bası, İstanbul 1959.

VIDAL Georges/MAGNOL, Joseph: Ceza Hukuku, (Çev: Şinası Z. Devrin), Ankara 1946.

VON HIPPEL, Eike: "Staatliche Entschädigung für Verbrechensopfer", ZRP, (1), 1971, s.5-7.

VONMAYENBURG, David: "Geborene Opfer”, Zeitschrift des Max-Planck-Instituts für europäische Rechtsgeschichte, 14,2009 , s.122-147.

VON THUR, Andreas: Der Allgemeine Teil des Deutschen Bürgerlichen Rechts, Band 1: Allgemeine Lehren und Personenrecht, 1.Bası, Leibzig 1910.

WALINE, Marcel:“Törel Kişilik Kuramı”, (Çev: Hamide Uzbark), AÜHFD, 2, 1945, s.306-322.

WEBSTER'S THIRD NEW INTERNATIONAL DICTIONARY, Springfied, Massachusets 2002.

WERTHEIMER, Alan: "Victimless Crimes", Ethics, 87(4), 1977, s.302-318.

WIELING, Hans Josef: Sachenrecht, Band 1, Sachen, Besitz und Rechte an beweglichen Sachen, 2.Bası, Berlin Heidelberg 2006.

WILHELM, Jan: Sachenrecht, 4.Bası, Göttingen 2010.

YALÇIN, Türkan/KÖPRÜLÜ, Timuçin: Ceza Hukuku Genel Hükümler Uygulamalı Çalışmaları, 6.Bası, Ankara 2019. YELBAŞı, Cengiz: Fransızca-İngilizce-Almanca Karşılıklarılla Ansiklopedik Hukuk Sözlüğü, 1.Bası, Ankara 2014.

YILDIZ, Ali Kemal: Ceza Muhakemesi Hukukunda Mağdur - Suçtan Zarar Gören - Şikâyetçi, 1.Bası, Ankara 2008.

YURTCAN, Erdener: Şahsi Dava ve Uygulaması, 3.Bası, Ankara 1989.

YÜCEL, Mustafa Tören: Suç ve Ceza Anatomisi (Anatomisi), Ankara 1973.

YÜCEL, Mustafa Tören: Türk Ceza Siyaseti ve Kriminolojisi (Ceza), 4.Bas1, Ankara 2007.

ZAFER, Hamide: Ceza Hukuku Genel Hükümler, İstanbul 2013.

ZERRES, Thomas: Bürgerliches Recht: Eine Einführung in das Zivilrecht und die Grundzüge des Zivilprozessrechts, 7.Bas1, Berlin Heidelberg 2013. 